\title{
Oxygen isotope composition of waters recorded in carbonates in strong clumped and oxygen isotopic disequilibrium
}

\author{
Caroline Thaler, Amandine Katz, Magali Bonifacie, Bénédicte Ménez, and Magali Ader \\ Université de Paris, Institut de physique du globe de Paris, CNRS, 75005 Paris, France \\ Correspondence: Caroline Thaler (thaler.caroline@gmail.com)
}

Received: 25 November 2019 - Discussion started: 11 December 2019

Revised: 20 February 2020 - Accepted: 26 February 2020 - Published: 3 April 2020

\begin{abstract}
Paleoenvironmental reconstructions, which are mainly retrieved from oxygen isotope $\left(\delta^{18} \mathrm{O}\right)$ and clumped isotope $\left(\Delta_{47}\right)$ compositions of carbonate minerals, are compromised when carbonate precipitation occurs in isotopic disequilibrium. To date, knowledge of these common isotopic disequilibria, known as vital effects in biogenic carbonates, remains limited, and the potential information recorded by $\delta^{18} \mathrm{O}$ and $\Delta_{47}$ offsets from isotopic equilibrium values is largely overlooked. Additionally, in carbonates formed in isotopic equilibrium, the use of the carbonate $\delta^{18} \mathrm{O}$ signature as a paleothermometer relies on our knowledge of the paleowaters' $\delta^{18} \mathrm{O}$ value, which is often assumed. Here, we report the largest $\Delta_{47}$ offsets observed to date (as much as $-0.270 \%$ ), measured on microbial carbonates that are strongly linked to carbonate $\delta^{18} \mathrm{O}$ offsets $(-25 \%$ ) from equilibrium. These offsets are likely both related to the microorganism metabolic activity and yield identical erroneous temperature reconstructions. Unexpectedly, we show that the $\delta^{18} \mathrm{O}$ value of the water in which carbonates precipitated, as well as the water-carbonate $\delta^{18} \mathrm{O}$ fractionation dependence on temperature at equilibrium, can be retrieved from these paired $\delta^{18} \mathrm{O}$ and $\Delta_{47}$ disequilibrium values measured in carbonates. The possibility to retrieve the $\delta^{18} \mathrm{O}$ value of paleowaters, sediments' interstitial waters or organisms' body water at the carbonate precipitation loci, even from carbonates formed in isotopic disequilibrium, opens long-awaited research avenues for both paleoenvironmental reconstructions and biomineralization studies.
\end{abstract}

\section{Introduction}

Oxygen isotope composition $\left(\delta^{18} \mathrm{O}\right)$ paired with clumped isotope composition $\left(\Delta_{47}\right)$ of carbonate minerals is increasingly used for reconstructing paleoenvironmental or diagenetic conditions (Ghosh et al., 2006; Henkes et al., 2018; Mangenot et al., 2018a, b). The $\delta^{18} \mathrm{O}$ of carbonates depends on both the $\delta^{18} \mathrm{O}$ value of the water in which the carbonate precipitated and the precipitation temperature (Urey et al., 1951). Its use to reconstruct paleoenvironments can be combined with the new carbonate $\mathrm{C}-\mathrm{O}$ "clumped isotope" abundance $\left(\Delta_{47}\right)$ thermometer which depends only on the carbonate precipitation temperature (Ghosh et al., 2006). By combining the $\Delta_{47}$-derived temperatures and the carbonate $\delta^{18} \mathrm{O}$ value $\left(\delta^{18} \mathrm{O}_{\text {carbonate }}\right)$, the $\delta^{18} \mathrm{O}$ value of the water $\left(\delta^{18} \mathrm{O}_{\text {water }}\right)$ in which the carbonate precipitated can be retrieved. However, this requires that solid carbonate and water reached isotopic equilibrium, which is often hard to prove. Conversely, carbonate precipitation in isotopic disequilibrium is commonly encountered (Affek et al., 2014; Loyd et al., 2016). Out of equilibrium, $\delta^{18} \mathrm{O}$ and $\Delta_{47}$ values are particularly known to occur in biogenic carbonates (Thiagarajan et al., 2011; Bajnai et al., 2018) - the most abundant carbonates in the sedimentary record. To date, the reasons for these isotopic disequilibria in carbonates remain largely under-constrained. While $\Delta_{47}$ compositions of carbonates seemed at first free of any biologically driven or mineral-specific fractionation known to affect $\delta^{18} \mathrm{O}_{\text {carbonate }}$ compositions (Eiler, 2011), recently identified disequilibrium $\Delta_{47}$ values (Saenger et al., 2012; Affek, 2013; Tang et al., 2014; Burgener et al., 2018) shed new light on and help to unravel the mechanisms responsible for oxygen isotopic disequilibrium in carbonate minerals. Even though the identification of these vital effects does not prevent $\delta^{18} \mathrm{O}$ and $\Delta_{47}$ tools from being pow- 
erful paleothermometers as empirical calibrations taking vital effects into account allow temperature reconstructions, it has become crucial to determine if the $\delta^{18} \mathrm{O}$ and $\Delta_{47}$ disequilibria observed in carbonates as diverse as those found in coral reefs (Saenger et al., 2012), brachiopods (Bajnai et al., 2018), microbialites and methane seep carbonates (Loyd et al., 2016) along with speleothems (Affek et al., 2014) could be explained by oxygen isotope disequilibria occurring in dissolved inorganic carbon (DIC) involved in carbonate precipitation. In this case, $\delta^{18} \mathrm{O}$ and $\Delta_{47}$ disequilibria in biogenic carbonates would record information, however unavailable yet, on the physiological characteristics of carbonate-forming organisms.

In previous experiments we produced microbial calcium carbonates (Millo et al., 2012; Thaler et al., 2017) that recorded the strongest oxygen isotope disequilibrium ever identified between DIC and precipitation water (i.e., $-25 \%$ o offset from $\delta^{18} \mathrm{O}_{\text {carbonate }}$ equilibrium values). We used carbonic anhydrase (CA), an enzyme able to accelerate oxygen isotope equilibration between DIC and water via fast $\mathrm{CO}_{2}$ hydration and $\mathrm{HCO}_{3}^{-}$dehydration. When CA was added to the precipitation water, the carbonate oxygen isotope compositions reached equilibrium with the precipitation water (Thaler et al., 2017). Here, we build on these experiments as they offer a unique opportunity to assess experimentally whether carbonates precipitated from DIC in disequilibrium with water also record $\Delta_{47}$ disequilibrium values and the type of information that is actually carried by these paired disequilibria. We later show how and to what extent this can be applied to previously published cases of oxygen isotopic offsets from equilibrium values in both biogenic and abiotic carbonates.

\section{Materials and methods}

\subsection{Precipitation of microbial carbonates}

Carbonates were precipitated at $30 \pm 0.1^{\circ} \mathrm{C}$ using the procedure detailed in Millo et al. (2012) and Thaler et al. (2017) and summarized hereafter. The precipitation solution (initial $\mathrm{pH}=6.0$ ) was composed of ions added to Milli- $\mathrm{Q}^{\circledR}$ water (resistivity $=18 \mathrm{M} \Omega \mathrm{cm}$ ) by dissolving salts in the following order: $\mathrm{MgSO}_{4} \cdot 7 \mathrm{H}_{2} \mathrm{O}(16 \mathrm{mM}), \mathrm{NaCl}(80 \mathrm{mM}), \mathrm{KCl}(4 \mathrm{mM})$, urea $(33.3 \mathrm{mM})$ and $\mathrm{CaCl}_{2}(40 \mathrm{mM})$. The aim was to mimic the ionic composition of groundwater (Millo et al., 2012). In experiments with CA whose $\delta^{18} \mathrm{O}$ results (but not the $\Delta_{47}$ ones) were recently published in Thaler et al. (2017), the precipitation solution was supplemented with CA at a concentration of $2 \mathrm{mg} \mathrm{L}^{-1}$. The precipitation solution (with or without $\mathrm{CA}$ ) was then mixed at a volumetric ratio of $1: 1$ with the ureolytic soil bacteria Sporosarcina pasteurii (Fig. 1) suspended in Milli- $Q^{\circledR}$ water, at a final optical density at $600 \mathrm{~nm}$ of $0.100 \pm 0.010$. For this study, 16 gastight Exetainer ${ }^{\circledR}$ vials were filled with the precipitation solution without $\mathrm{CA}$ in or- der to sacrifice them at regular time intervals (i.e., 30, 60, 120,180 and $360 \mathrm{~min}$ and $24 \mathrm{~h}$ ) and thus obtain information on the kinetics of the reaction, while reproducing the procedure followed for the experiment with CA (Thaler et al., 2017) consisting of 27 vials sacrificed every 10 to $30 \mathrm{~min}$ and after $24 \mathrm{~h}$. The vials capped with rubber septa were filled up to the brim, i.e., without headspace, hence preventing any gaseous exchange with the atmosphere or headspace gases.

Ureolysis corresponds to two types of hydrolysis: (i) the hydrolysis of urea into ammonia $\left(\mathrm{NH}_{3}\right)$ and carbamate $\left(\mathrm{H}_{2} \mathrm{~N}-\mathrm{COOH}\right)\left(\mathrm{H}_{2} \mathrm{~N}-\mathrm{CO}-\mathrm{NH}_{2}+\mathrm{H}_{2} \mathrm{O} \rightarrow \mathrm{NH}_{3}+\mathrm{H}_{2} \mathrm{~N}\right.$ $\mathrm{COOH}$ ), which is catalyzed by urease and is the rate-limiting step, and (ii) the rapid and spontaneous hydrolysis of carbamate into ammonia and $\mathrm{CO}_{2(\mathrm{aq})}$ $\left(\mathrm{H}_{2} \mathrm{~N}-\mathrm{COOH}+\mathrm{H}_{2} \mathrm{O} \rightarrow \mathrm{NH}_{3}+\mathrm{CO}_{2(\mathrm{aq})}+\mathrm{H}_{2} \mathrm{O}\right)$ (Krebs and Roughton, 1948; Matsuzaki et al., 2013) or $\mathrm{H}_{2} \mathrm{CO}_{3}\left(\mathrm{H}_{2} \mathrm{~N}\right.$ $\mathrm{COOH}+\mathrm{H}_{2} \mathrm{O} \rightarrow \mathrm{NH}_{3}+\mathrm{H}_{2} \mathrm{CO}_{3}$ ) (Mobley and Hausinger, 1989; Krajewska, 2009).

Ureolysis completion was followed by evaluating the production of dissolved inorganic nitrogen $\left(\mathrm{DIN}=\mathrm{NH}_{3}+\mathrm{NH}_{4}^{+}\right)$. Determination of $\mathrm{pH}$, DIN concentration and amount of precipitated carbonates (Fig. 2), as well as isotopic measurements, was performed for each vial to monitor their evolution as the ureolysis reaction progresses. The $\mathrm{pH}$ initially increased from 6.0 to 9.0 due to $\mathrm{NH}_{3}$ production by ureolysis and consecutive alkalinization of the precipitation solution (Fig. 2a). The subsequent carbonate precipitation (Fig. 2b) lowered $\mathrm{pH}$ to 8.6 (without CA) and 8.4 (with CA) and was followed by a second $\mathrm{pH}$ increase to 8.8 (without CA) and 8.7 (with CA) when carbonate precipitation stopped while ureolysis continued. At ureolysis completion, all the calcium initially present in solution (i.e., the limiting reagent) had precipitated whereas $35 \%$ to $45 \%$ of the DIC produced by ureolysis remained in solution. Carbonate precipitates, formed at the bottom and on the wall of the vials, were immediately rinsed with a few drops of pure ethanol in order to dehydrate bacteria and prevent further ureolysis, carbonate formation and/or dissolution-reprecipitation processes. Ethanol was then removed, and, prior to their collection, carbonates were dried overnight at $40^{\circ} \mathrm{C}$ in the vials placed in a ventilated oven equipped with desiccating beads. The majority of the carbonates precipitated in this study were composed of calcite with minor amounts of aragonite (1\% to $4 \%$ ), vaterite $(2 \%$ to $4 \%)$ and magnesian calcite with low $\mathrm{Mg}$ content $\left(\mathrm{Mg}_{0.064}, \mathrm{Ca}_{0.936}\right) \mathrm{CO}_{3}$ (up to $8 \%$ ) (Thaler et al., 2017).

All of the measured chemical parameters $(\mathrm{pH}$, DIC, amount of solid carbonates, $\mathrm{Ca}^{2+}$ concentration, DIN) along with DIC and solid carbonate $\delta^{13} \mathrm{C}$ behave similarly with or without active CA (Thaler et al., 2017). It was not possible to measure $\Delta_{47}$ for all the precipitated carbonates due to their low amount, particularly for the tubes sacrificed at the beginning of the experiments (Table S1 in the Supplement). 


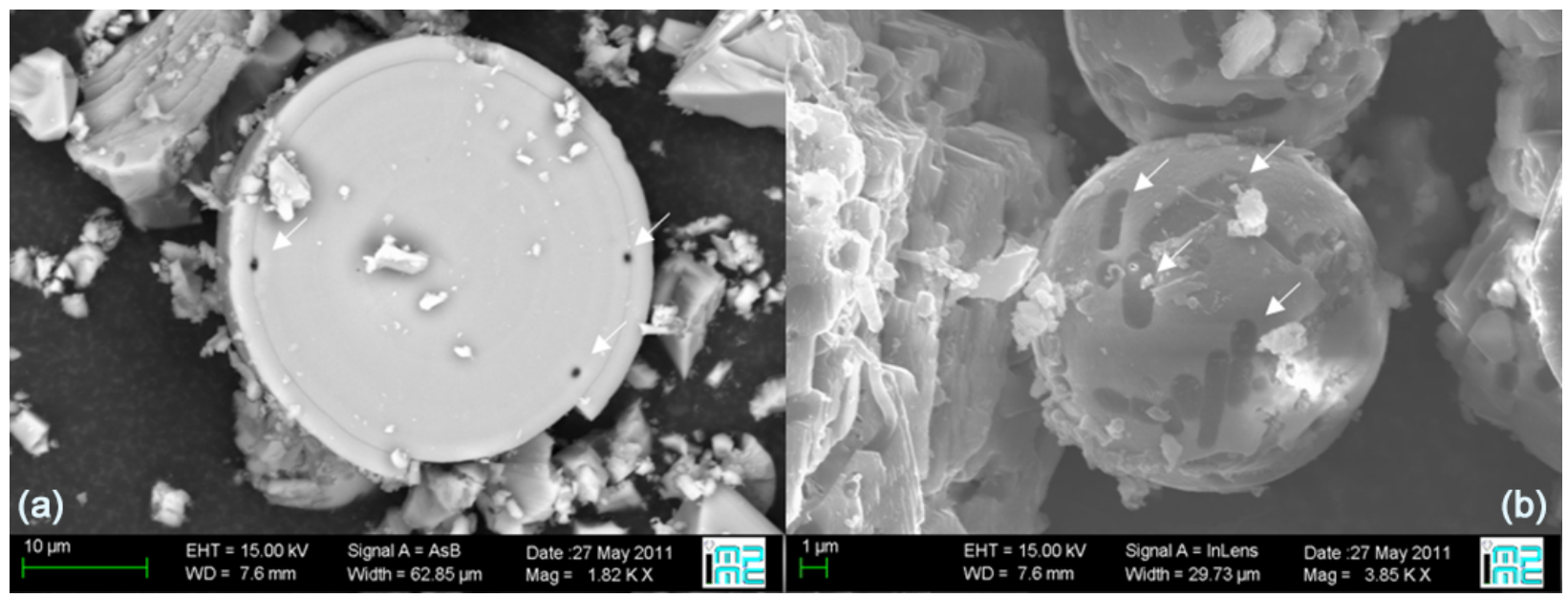

Figure 1. Scanning electron microscopy images of the bio-induced carbonates formed with CA (almost pure calcite and traces of vaterite and aragonite as determined using X-ray diffraction; Thaler et al., 2017). The fingerprints of Sporosarcina pasteurii cells are visible as black holes (a showing a cross section of carbonate) or as rods and indicated by white arrows.
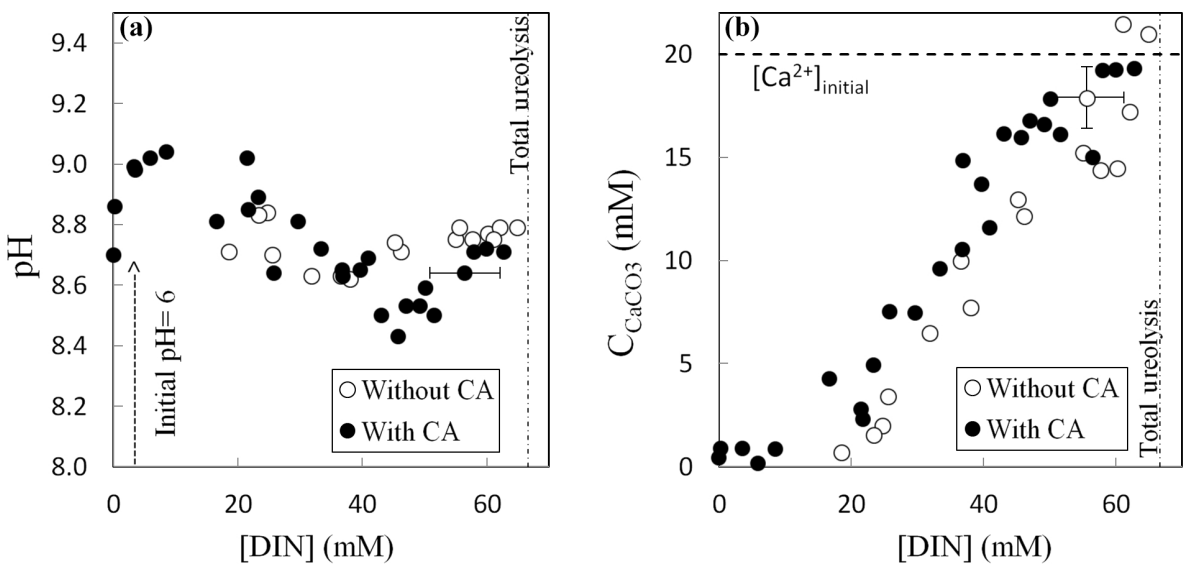

Figure 2. Evolution of $\mathrm{pH}$ (a) and amount of precipitated calcium carbonate $C_{\mathrm{CaCO}_{3}}$ (b) as a function of the production of dissolved inorganic nitrogen DIN (DIN $=\mathrm{NH}_{3}+\mathrm{NH}_{4}^{+}$) by bacteria during ureolysis, without carbonic anhydrase (CA) (this study) and with CA (data from Thaler et al., 2017). Error bars account for 2 SD and are always smaller than symbols for $\mathrm{pH}$ values. The mineralogy of the carbonates precipitated with or without CA was determined by X-ray diffraction, indicating that solid carbonates are mostly composed of calcite (including up to $8 \%$ of low-Mg calcite, $\left.\left(\mathrm{Mg}_{0.064}, \mathrm{Ca}_{0.936}\right) \mathrm{CO}_{3}\right)$, vaterite $(2 \%-4 \%)$ and aragonite (1\%-4\%) (Thaler et al., 2017). The influence of mineralogy on isotopic measurements and temperature estimates is discussed in the Supplement, Sect. S1.

\section{$2.2 \quad \delta^{18} \mathrm{O}$ and $\Delta_{47}$ measurements and associated uncertainties}

All the isotopic analyses were made at Institut de physique $\mathrm{du}$ globe de Paris (IPGP, France). $\delta^{18} \mathrm{O}$ analyses were performed on carbonate powders of ca. $2 \mathrm{mg}$ with a continuoushelium-flow isotope ratio mass spectrometer AP 2003 (Analytical Precision 2003, GV Instruments) coupled to a gas chromatograph column (GC-IRMS, Chrompac Column Type 99960), as described in Millo et al. (2012) and Thaler et al. (2017). External reproducibility on carbonate standards is $\pm 0.1 \%$ ( $1 \mathrm{SD})$ and represents the uncertainty assigned to $\delta^{18} \mathrm{O}_{\text {carbonate data. }}$
The analytical procedure used for clumped isotope $\Delta_{47}$ measurements is only briefly presented here and detailed in Bonifacie et al. (2017). About $5 \mathrm{mg}$ of carbonates was digested at $90^{\circ} \mathrm{C}$ for $20 \mathrm{~min}$ with $104 \%$ phosphoric acid $\mathrm{H}_{3} \mathrm{PO}_{4}$ in a common acid bath. The produced gaseous $\mathrm{CO}_{2}$ was purified with a manual vacuum line before introduction into a Thermo Scientific MAT 253 dual-inlet mass spectrometer. Each purified $\mathrm{CO}_{2}$ gas was analyzed for its abundance in isotopologues with $\mathrm{m} / \mathrm{z}$ from 44 to 49 versus a working gas provided by Oztech Trading Corporation with $\delta^{13} \mathrm{C}=-3.71 \%$ Vienna Pee Dee Belemnite (VPDB) and $\delta^{18} \mathrm{O}=+24.67 \%$ Vienna Standard Mean Ocean Water (VS$\mathrm{MOW}$ ), as determined with the international reference ma- 
terial NBS19. One single $\Delta_{47}$ measurement corresponds to 70 cycles of $26 \mathrm{~s}$ integration time each (total integration time $=1820 \mathrm{~s}$ ). Conventional $\delta^{18} \mathrm{O}$ and $\delta^{13} \mathrm{C}$ data were also acquired simultaneously with $\Delta_{47}$ measurements with this instrument (Tables S1 and S2). They are in excellent consistency with data obtained with the continuous-flow method on smaller samples (Table S1).

The $\Delta_{47}$ is calculated as a function of the stochastic distribution of the $\mathrm{CO}_{2}$ isotopologues, as follows:

$$
\begin{aligned}
\Delta_{47} & =\left[\left(\frac{R_{\text {measured }}^{47}}{R_{\text {stochastic }}^{47}}-1\right)-\left(\frac{R_{\text {measured }}^{46}}{R_{\text {stochastic }}^{46}}-1\right)\right. \\
& \left.-\left(\frac{R_{\text {measured }}^{45}}{R_{\text {stochastic }}^{45}}-1\right)\right] \times 1000,
\end{aligned}
$$

where $\Delta_{47}$ is expressed in per mill (\%o), and $R^{47}, R^{46}$ and $R^{45}$ are the abundance ratios of the masses 47,46 and 45 , respectively, relative to the mass $44\left({ }^{12} \mathrm{C}^{16} \mathrm{O}^{16} \mathrm{O}\right) . R_{\text {measured }}^{X}$ denotes measured ratios of the $\mathrm{CO}_{2}$ sample. $R_{\text {stochastic }}^{X}$ values are calculated from the measured $44,45,46$ and 47 abundance ratios. The number of isotopologues of mass 47 (mainly ${ }^{13} \mathrm{C}^{18} \mathrm{O}^{16} \mathrm{O}$, but also ${ }^{12} \mathrm{C}^{17} \mathrm{O}^{16} \mathrm{O}$ and ${ }^{13} \mathrm{C}^{17} \mathrm{O}^{17} \mathrm{O}$ ) measured within the $\mathrm{CO}_{2}$ sample extracted from the acid digestion of the carbonates is linked to the number of isotopologues of mass 63 (mainly ${ }^{13} \mathrm{C}^{18} \mathrm{O}^{16} \mathrm{O}^{16} \mathrm{O}$ ) within the reacted carbonate mineral (Guo et al., 2009). For the correction from ${ }^{17} \mathrm{O}$ interferences, we used the ${ }^{17} \mathrm{O}$ correction parameters from Brand et al. (2010), as recently recommended (Daëron et al., 2016; Schauer et al., 2016). In order to transfer the obtained raw $\Delta_{47}$ data into the absolute carbon dioxide equilibrium scale "CDES" $\left(\Delta_{47}\right.$ CDES90 being the $\Delta_{47}$ values of carbonates reacted within acid at $90^{\circ} \mathrm{C}$ ), standards of $\mathrm{CO}_{2}$ gases equilibrated at 25 and $1000^{\circ} \mathrm{C}$ and with bulk isotopic compositions covering the range of measured carbonate samples $\left(\delta^{47}\right.$ values between $-50 \%$ and $+24 \%$ ) were analyzed interspaced with unknown samples (typically 15 equilibrated $\mathrm{CO}_{2}$ gas analyses by discrete session of analysis, four analytical sessions in total; Table S5). For each analytical session, as recommended in Dennis et al. (2011), the $\Delta_{47}$ data were finally corrected with a fixed equilibrated gas line slope (only slightly varying from 0.0048 to 0.0062 over our analytical sessions) and an empirical transfer function (slopes varying from 1.0859 to 1.1344 ) based on the equilibrated $\mathrm{CO}_{2}$ standards. Finally, the accuracy of our whole dataset and processing procedure was validated on carbonate reference material (i.e., IPGP-Carrara and 102-GC-AZ01), typically analyzed every two unknown samples (Table S5). The $\Delta_{47}$ values obtained at IPGP over the course of this study are $\Delta_{47 \mathrm{CDES} 90}=0.316 \pm 0.020 \%$ ( $\left.1 \mathrm{SD}, n=16\right)$ for IPGPCarrara and $\Delta_{47 \mathrm{CDES} 90}=0.620 \pm 0.010 \%$ o $(1 \mathrm{SD}, n=18)$ for 102-GC-AZ01. Those values are indistinguishable from the values obtained at IPGP over 4 years of analyses on the same instrument $(n>300)$ or previously reported by other laboratories (Daëron et al., 2016).

\subsection{Temperature estimates and associated uncertainties}

Apparent temperatures obtained from oxygen isotope compositions were calculated based on the measured $\delta^{18} \mathrm{O}_{\text {carbonate }}$ values of both the precipitated carbonate and the precipitation water in each experimental vial (Table S1) and using the equation of oxygen isotopes' fractionation between calcite and water from Kim and O'Neil (1997). Apparent temperatures issued from clumped isotope compositions were calculated from $\Delta_{47}$ CDES90 data using the composite universal $\Delta_{47}-T$ calibration (Eq. 3 from Bonifacie et al., 2017, with $T$, the temperature). It is noteworthy that our main observations and conclusions do not change if other calibrations to temperature are used for $\delta^{18} \mathrm{O}$ and/or $\Delta_{47}$ (e.g., Coplen, 2007; Kelson et al., 2017) (see also Table S3). For both proxies, the uncertainties on temperature estimates reported here correspond to the standard deviation of the mean of replicated isotopic measurements of the same powder propagated in the calibration equation (but the actual errors on the calibration themselves are not considered). Note that the long-term external reproducibility on homogeneous calcite reference materials found in this study (i.e., $\pm 0.020 \%$, $1 \mathrm{SD}$ ) is used for samples with only one measurement or with 1 SD lower than $0.020 \%$ (Tables S1 and S5, Sect. S1 in the Supplement).

For the temperature $(T)$ derived from the $\Delta_{47}$ data, we chose the calibration determined by Bonifacie et al. (2017) as it integrates a consequent number of data $(n>300)$, whose statistical weight has been properly considered and covers a wide temperature range (from 1 to $350^{\circ} \mathrm{C}$ ), three characteristics that were recently shown by several teams as governing the precision on $\Delta_{47}-T$ calibration equations (Bonifacie et al., 2017; Kelson et al., 2017; Fernandez et al., 2017). Importantly, this calibration covers the high apparent temperature ranges reported here (i.e., low $\Delta_{47}$ values) allowing us to avoid loss of precision and accuracy when extrapolating to temperature ranges that have not been experimentally investigated. Finally the Bonifacie et al. (2017) calibration has been checked independently with other methods (Mangenot et al., 2017; Dassié et al., 2018) on the range of temperatures $\left(\sim 30\right.$ to $\left.96^{\circ} \mathrm{C}\right)$ where most available calibrations diverge and/or are not well constrained. Indeed, these studies report excellent consistencies: (i) between $T \Delta_{47}$ and homogenization temperatures from fluid inclusion microthermometry (Mangenot et al., 2017) and (ii) between the $\delta^{18} \mathrm{O}_{\text {water val- }}$ ues directly measured in fluid inclusions by cavity ring-down spectroscopy and those calculated from combined $T \Delta_{47}$ and $\delta^{18} \mathrm{O}_{\text {carbonate }}$ of the host mineral (Dassié et al., 2018). Though we recognize that the normalization to carbonate standards presented in Bernasconi et al. (2018) might become commonly used by the community in the future (i.e., with the ongoing intercomparison InterCarb project), we preferred not to use this correction frame here because not enough of the four carbonate standards proposed by Bernasconi et al. (2018) were run together with our samples $(n=14$ runs in total of 
ETH1, ETH2, ETH3 and ETH4 standards; Table S5), and such a normalization method will then introduce larger uncertainty than the normalization we performed with the large number of equilibrated gases ran daily together with our unknowns ( $n=104$ equilibrated gas; Table S5 - note also 33 secondary carbonate standards 102-GC-AZ01 and IPGPCararra, also run in other IPGP studies and some other laboratories). Also remarkably, $\Delta_{47}$ values obtained here on the four ETH carbonate standards are all systematically higher than values reported in Bernasconi et al. (2018) (Table S4). Though the reason for this positive offset is still unclear, it is noteworthy that positive offsets are also observed when compiling other recent published values (Table S4; Daëron et al., 2016; Schauer et al., 2016; Fiebig et al., 2019).

\section{Results and discussion}

\section{1 $\Delta_{47}$ and $\delta^{18} O$ compositions of microbial carbonates can present strongly correlated vital effects}

We performed $\Delta_{47}$ measurements on (i) microbial carbonates precipitated without $\mathrm{CA}$ by faithfully replicating the experiment detailed in Thaler et al. (2017) and (ii) microbial carbonates precipitated in the presence of $\mathrm{CA}$ remaining from these experiments. These calcium carbonates were precipitated as the result of microbially driven hydrolysis of urea into DIC and ammonia (Millo et al., 2012). They constitute a reliable model for carbonate precipitation triggered by enzymatic production or transport of DIC, as is the case for microand macro-skeletal carbonates common in the Phanerozoic and for microbially mediated carbonates since the Precambrian.

Without CA, the isotopic values of the very first carbonate precipitates present strong isotopic offsets from equilibrium values. The $\Delta_{47}$ offset to equilibrium starts from $-0.270 \%$ (the largest $\Delta_{47}$ offset ever measured in solid carbonates), and the offset to equilibrium reaches $-24.7 \%$ o for $\delta^{18} \mathrm{O}_{\text {carbonate }}$ (Fig. 3 and Table S1). Both $\Delta_{47}$ and $\delta^{18} \mathrm{O}_{\text {carbonate }}$ absolute values then increase as ureolysis progresses, reducing offsets from equilibrium values to $-0.179 \%$ o for $\Delta_{47}$ and $-15.7 \%$ for $\delta^{18} \mathrm{O}_{\text {carbonate. In }}$ the presence of CA, the trends observed for the $\Delta_{47}$ and

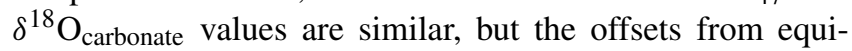
librium are drastically reduced (down to $-0.027 \%$ for $\Delta_{47}$ and $-1.4 \%$ for $\delta^{18} \mathrm{O}_{\text {carbonate }}$ at the end of the experiment; Fig. 3), hence attesting for ongoing isotopic equilibration of DIC with water by CA enzymatic activity prior to and during carbonate precipitation. The comparable behavior of $\Delta_{47}$ and $\delta^{18} \mathrm{O}_{\text {carbonate values with respect to CA suggests that both }}$ disequilibria are inherited from the $\delta^{18} \mathrm{O}$ and $\Delta_{47}$ signatures of the DIC generated by the biological activity.

\section{2 $\Delta_{47}$ and $\delta^{18} \mathrm{O}_{\text {carbonate }}$ disequilibrium originates from the metabolic production of DIC}

Here, we discuss the potential processes known to generate $\delta^{18} \mathrm{O}$ and $\Delta_{47}$ isotope fractionations during carbonate precipitation and we identify the main mechanism explaining our paired $\Delta_{47}$ and $\delta^{18} \mathrm{O}_{\text {carbonate }}$ disequilibria. The relatively high precipitation rate $(R)$ in our experiments $(\log R=$ $-3.95 \mathrm{~mol} \mathrm{~m}^{-2} \mathrm{~s}^{-1}$; Thaler et al., 2017) can only account for an oxygen kinetic isotope fractionation (KIF) of about $1 \%$ o to $2 \%$ o for $\delta^{18} \mathrm{O}$ values (Watkins et al., 2013), while the oxygen isotope disequilibrium recorded in our carbonates reaches $-24.7 \%$. Degassing of $\mathrm{CO}_{2}$, known to fractionate DIC oxygen isotopes (Affek and Zaarur, 2014), can be ruled out as there is no gas phase in our experiments (see Sect. 2.1). Any potential kinetic fractionation due to DIC diffusion (Thiagarajan et al., 2011) is also unlikely as precipitation occurred on the bacterial DIC-producing cells, as highlighted by scanning electron microscopy showing bacterial cells trapped within and at the surface of carbonate crystals (Fig. 1). Accordingly, the large offsets from equilibrium values observed for both $\Delta_{47}$ and $\delta^{18} \mathrm{O}$ in our microbial carbonates can only result from (i) a KIF induced by $\mathrm{CO}_{2}$ hydration or hydroxylation into $\mathrm{HCO}_{3}^{-}$(but only if ureolysis produces $\mathrm{CO}_{2}$ rather than $\mathrm{H}_{2} \mathrm{CO}_{3}$, which has not been established yet; Matsuzaki et al., 2013) or (ii) a metabolic isotopic signature of the DIC produced by the bacteria, inherited from the initial isotopic composition of urea and/or due to a KIF introduced by the urease enzyme. $\mathrm{CO}_{2}$ hydration and hydroxylation lead to the formation of $\mathrm{HCO}_{3}^{-}$, with two oxygen atoms coming from $\mathrm{CO}_{2}$ and the third one from $\mathrm{H}_{2} \mathrm{O}$ (hydration) or $\mathrm{OH}^{-}$(hydroxylation). The $\delta^{18} \mathrm{O}_{\mathrm{HCO}_{3}^{-}}$value can then be estimated using a simple mass balance calculation (Létolle et al., 1990; Usdowski et al., 1991). The newly formed $\mathrm{HCO}_{3}^{-}$is depleted in ${ }^{18} \mathrm{O}$ compared to the reacting $\mathrm{CO}_{2}$ because of the incorporation of oxygen coming from $\mathrm{H}_{2} \mathrm{O}$ or $\mathrm{OH}^{-}$, both depleted in ${ }^{18} \mathrm{O}$ relative to ${ }^{16} \mathrm{O}$ in contrast to $\mathrm{CO}_{2}$ (Green and Taube, 1963; Beck et al., 2005). Such a low $\delta^{18} \mathrm{O}_{\mathrm{HCO}_{3}^{-}}$value, several per mill lower than the equilibrium one, can then be preserved in the calcium carbonate if precipitation occurs shortly after $\mathrm{CO}_{2}$ hydration and hydroxylation and before the full equilibration with water (Rollion-Bard et al., 2003). Regarding clumped isotopes, ab initio calculations predict that the fractionation associated with $\mathrm{CO}_{2}$ hydration and hydroxylation increases the relative abundance of ${ }^{13} \mathrm{C}-$ ${ }^{18} \mathrm{O}$ bonds and thus the $\Delta_{47}$ value (Guo, 2009). Even though this predicted fractionation trend has previously been used to explain several datasets for which $\mathrm{CO}_{2}$ hydroxylation was assumed to occur prior to carbonate precipitation (Tripati et al., 2015; Spooner et al., 2016), such a tendency can only be validated using data acquired on carbonates for which $\mathrm{CO}_{2}$ hydration and hydroxylation are demonstrated. This is the case of (i) hyperalkaline travertines (Falk et al., 2016) even though part of the reported kinetic isotope fractionation 

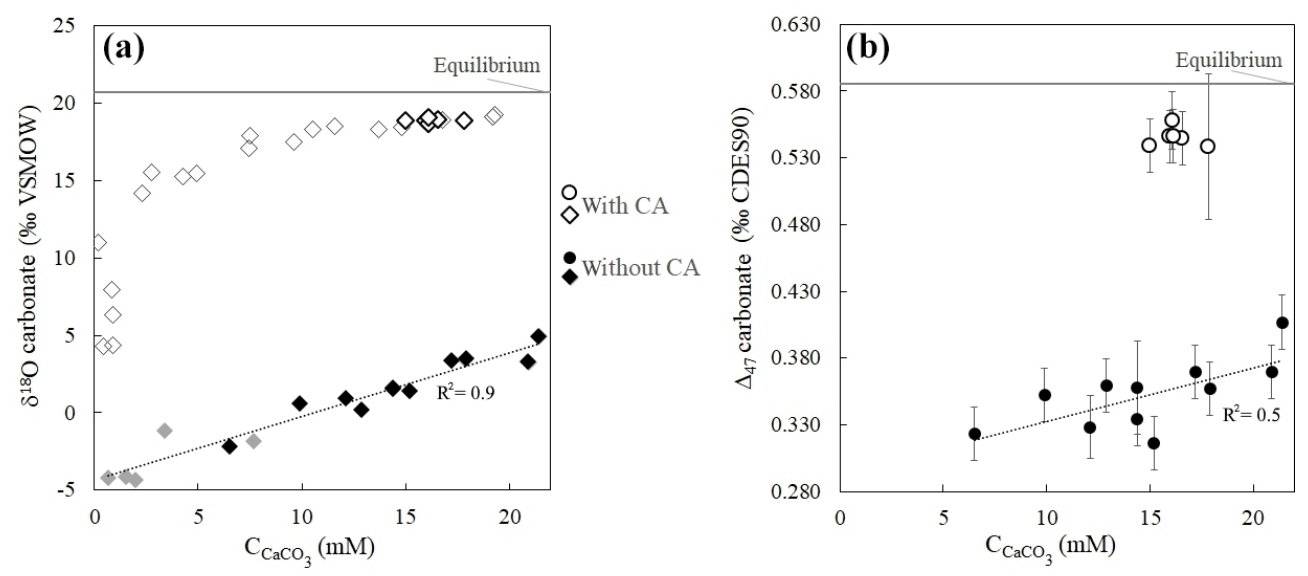

Figure 3. Strong $\delta^{18} \mathrm{O}$ and $\Delta_{47}$ disequilibria recorded in microbial carbonates as shown by $\delta^{18} \mathrm{O}_{\text {carbonate }}(\mathbf{a})$ and $\Delta_{47}$ (b) values of calcium carbonates $\left(\mathrm{CaCO}_{3}\right)$ precipitated during bacterial ureolysis at $30^{\circ} \mathrm{C}$ (with and without carbonic anhydrase, CA; open and solid symbols, respectively) as a function of carbonate accumulation $\left(C_{\mathrm{CaCO}_{3}}\right)$. Black symbols correspond to samples for which both $\Delta_{47}$ and $\delta^{18} \mathrm{O}$ measurements were performed. The grey horizontal lines are equilibrium $\delta^{18} \mathrm{O}_{\text {carbonate }}$ and $\Delta_{47}$ values at $30^{\circ} \mathrm{C}$ for calcite following Bonifacie et al. (2017) and Kim and O'Neil (1997) calibrations, respectively. Uncertainties (1 standard deviation, 1 SD) are smaller than the symbol for $\delta^{18} \mathrm{O}$ and $C_{\mathrm{CaCO}_{3}}$ values (Table S1). Reported $\Delta_{47}$ uncertainties are detailed in Sect. 2 and Sect. S1 in the Supplement.

can be interpreted as resulting from the $\mathrm{CO}_{2}$ dissolution process (Clark et al., 1992) and (ii) two experimental samples (Tang et al., 2014) precipitated at high $\mathrm{pH}$ where $\mathrm{CO}_{2}$ hydroxylation dominates. Both studies show, in agreement with the ab initio calculations (Guo, 2009), higher $\Delta_{47}$ and lower $\delta^{18} \mathrm{O}_{\text {carbonate }}$ values compared to equilibrium. Thus, in a case where ureolysis would produce $\mathrm{CO}_{2}$ in isotopic equilibrium with water, the $\Delta_{47}$ values affected by $\mathrm{CO}_{2}$ hydration and hydroxylation recorded in calcium carbonates should be higher than the equilibrium value, while our microbial carbonates show $\Delta_{47}$ values lower than equilibrium. Thus, we conclude that our low $\Delta_{47}$ values measured in carbonates can only be explained by a metabolic source effect. In our case it corresponds to the ureolytic production of DIC, either directly as $\mathrm{H}_{2} \mathrm{CO}_{3}$ or as $\mathrm{CO}_{2}$, with a $\Delta_{47}$ value low enough to compensate for any potentially succeeding increase due to the KIF associated with $\mathrm{CO}_{2}$ hydration and hydroxylation. Nonetheless, the slow but continuous increase observed in our experiment without $\mathrm{CA}$ for both $\Delta_{47}$ and $\delta^{18} \mathrm{O}_{\text {carbonate }}$ values more likely reflects ongoing equilibration of DIC oxygen isotopes with water at a slow rate.

Our results highlight that the isotope clumping proceeds continuously as $\mathrm{C}-\mathrm{O}$ bonds are breaking and reforming in the DIC, allowing oxygen isotopes $\left({ }^{16} \mathrm{O},{ }^{17} \mathrm{O}\right.$ and $\left.{ }^{18} \mathrm{O}\right)$ to be redistributed between $\mathrm{H}_{2} \mathrm{O}, \mathrm{OH}^{-}, \mathrm{H}_{2} \mathrm{CO}_{3}, \mathrm{HCO}_{3}^{-}$and $\mathrm{CO}_{3}^{2-}$ species via $\mathrm{H}_{2} \mathrm{O} / \mathrm{OH}^{-}$attachment to $\mathrm{CO}_{2}$ and detachment from $\mathrm{HCO}_{3}^{-}$. In the experiment with CA, both $\Delta_{47}$ and $\delta^{18} \mathrm{O}_{\text {carbonate }}$ simultaneously reach values close to equilibrium, and without CA both $\Delta_{47}$ and $\delta^{18} \mathrm{O}_{\text {carbonate }}$ values increase simultaneously. This coevolution corroborates former observations of comparable kinetics for clumped isotopes and $\delta^{18} \mathrm{O}$ equilibration between DIC and water or $\mathrm{CO}_{2}$ and water once $\delta^{13} \mathrm{C}$ is equilibrated (Affek, 2013; Clog et al., 2015). This principle has been used to correct for the disequilibrium fractionation factor in speleothems (Affek et al., 2008).

\subsection{Erroneous yet comparable temperatures reconstructed from disequilibrium $\Delta_{47}$ and $\delta^{18} \mathrm{O}$ values in carbonates}

Apparent temperatures were calculated from disequilibrium $\Delta_{47}$ values obtained in the experiment without CA using the calibration of Bonifacie et al. (2017). Ranging from $198 \pm 21$ to $115 \pm 8^{\circ} \mathrm{C}$ (Fig. 4), they are at odds with the actual precipitation temperature of $30 \pm 1{ }^{\circ} \mathrm{C}$ (see Sect. 2.1). This shows that when carbonates precipitate from DIC in oxygen isotope disequilibrium with water, the abundance of ${ }^{13} \mathrm{C}-{ }^{18} \mathrm{O}$ bonds in carbonates does not correlate with precipitation water temperature. Conversely, the temperatures reconstructed from the $\Delta_{47}$ values of carbonates precipitated in the presence of $\mathrm{CA}$, ranging from $47 \pm 6$ to $39 \pm 2{ }^{\circ} \mathrm{C}$, are much closer to the actual precipitation temperature. Interestingly, the apparent temperatures reconstructed using Kim and O'Neil (1997) calibration from the $\delta^{18} \mathrm{O}_{\text {carbonate }}$ and $\delta^{18} \mathrm{O}_{\text {water values of the }}$ same samples show comparable offsets from the actual temperature in both experiments without CA (from $218 \pm 2$ to $139 \pm 1^{\circ} \mathrm{C}$ ) and with CA (from $39 \pm 1$ to $37 \pm 1^{\circ} \mathrm{C}$ ) (Fig. 4). Practically, this implies that similar temperatures calculated from both carbonate $\Delta_{47}$ and $\delta^{18} \mathrm{O}_{\text {carbonate }}$ values (in a case where the precipitation water $\delta^{18} \mathrm{O}$ can be determined) can neither constitute evidence against $\mathrm{O}$ isotope disequilibrium nor confirm that this is the true precipitation temperature. 


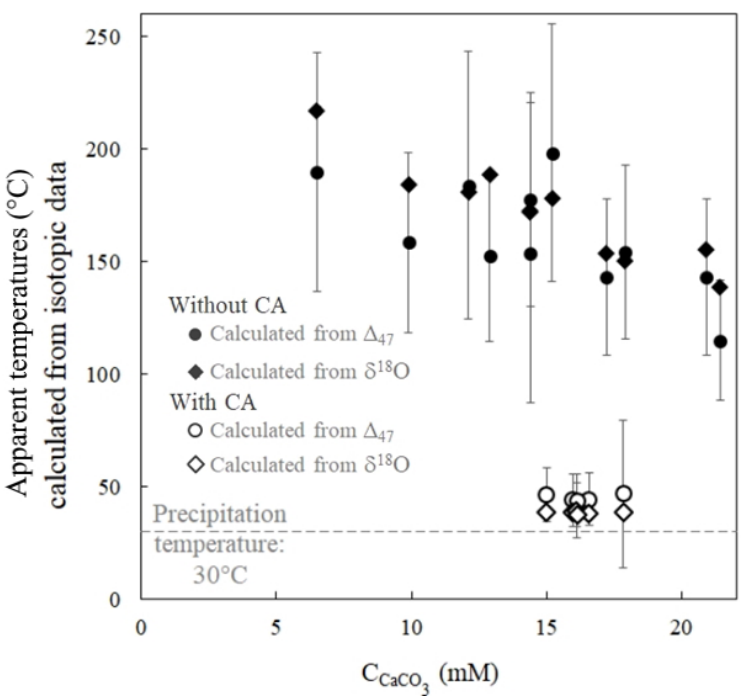

Figure 4. $\delta^{18} \mathrm{O}_{\text {carbonate }}$ and $\Delta_{47}$ disequilibria in microbial carbonates induce comparable biased estimates of precipitation temperature as illustrated by apparent temperatures calculated from the carbonate $\delta^{18} \mathrm{O}_{\text {carbonate }}$ and $\Delta_{47}$ signatures as a function of $\mathrm{CaCO}_{3}$ accumulation. Open and solid symbols refer to the experiments with and without $\mathrm{CA}$, respectively. The dashed grey line corresponds to the actual precipitation temperature. Apparent temperatures are respectively calculated from the $\delta^{18} \mathrm{O}_{\text {carbonate }}$ and $\Delta_{47}$ calibrations to the temperature of Kim and O'Neil (1997) and Bonifacie et al. (2017). Reported uncertainties were calculated as the propagation of the 1 standard deviation (1 SD) error of the isotopic data in the calibration equations (Sect. 2 and Sect. S1 in the Supplement).

\section{$3.4 \Delta_{47}$ and $\delta^{18} \mathrm{O}_{\text {carbonate }}$ paired disequilibria record the $\delta^{18} \mathrm{O}$ of the water in which the carbonates precipitated}

The fact that both $\Delta_{47}$ and $\delta^{18} \mathrm{O}_{\text {carbonate }}$ values permit us to calculate similarly evolving apparent temperatures along the (dis)equilibration profile recorded in carbonates as the experiment proceeds indicates that the $\delta^{18} \mathrm{O}_{\text {carbonate }}, \delta^{18} \mathrm{O}_{\text {water }}$, $\Delta_{47}$ and apparent temperature values are all together linked. In a diagram of $\Delta_{47}$ versus $\delta^{18} \mathrm{O}_{\text {carbonate, }}$, all of our data align, irrespectively of the fact that they are in strong isotopic disequilibrium or close to equilibrium (Fig. 5). Their alignment is fitted with what would be expected for equilibrium $\Delta_{47}$ and $\delta^{18} \mathrm{O}_{\text {carbonate }}$ values of calcite precipitated at various temperatures from water at a given $\delta^{18} \mathrm{O}_{\text {water }}$ value. This $\delta^{18} \mathrm{O}_{\text {water }}$ value can be calculated by combining, for the same temperature, the equations of $\Delta_{47}$ and $\delta^{18} \mathrm{O}_{\text {carbonate }}$ temperature calibrations from Bonifacie et al. (2017) and Kim and O’Neil (1997), respectively (Eq. 2):

$$
\begin{aligned}
\delta^{18} \mathrm{O}_{\text {water }} & =\exp \left\lfloor-\frac{18.03}{\sqrt{\frac{0.0422 \times 10^{6}}{\triangle_{47 \text { CDES90 }-0.1126}}}+32.42 \times 10^{-3}}\right. \\
& \left.+\ln \left(\delta^{18} \mathrm{O}_{\text {carbonate }}+1000\right)\right\rfloor-1000,
\end{aligned}
$$

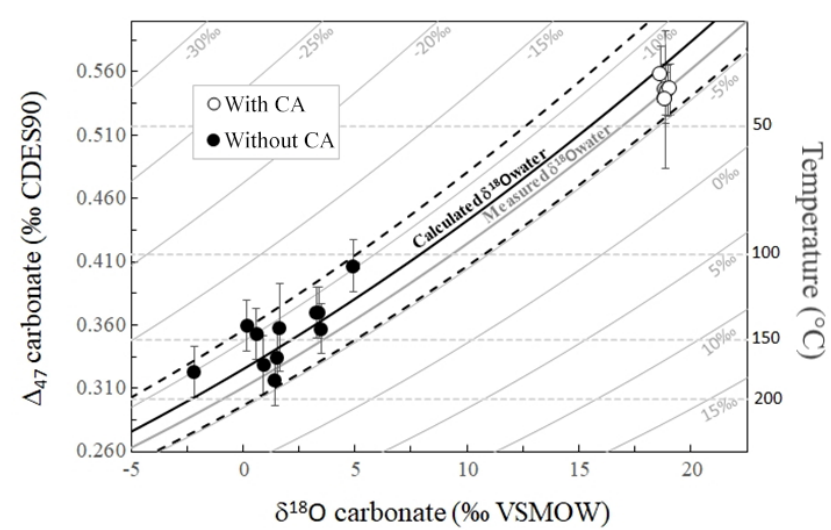

Figure 5. Combined $\delta^{18} \mathrm{O}_{\text {carbonate }}$ and $\Delta_{47}$ disequilibria of microbial carbonates precipitated at $30^{\circ} \mathrm{C}$ allow reconstruction of the $\delta^{18} \mathrm{O}$ of the water $\left(\delta^{18} \mathrm{O}_{\text {water }}\right)$ in which they precipitate. Solid grey curves represent the calculated $\Delta_{47}$ and $\delta^{18} \mathrm{O}_{\text {carbonate }}$ compositions of carbonates precipitated at oxygen isotope equilibrium from water with fixed $\delta^{18} \mathrm{O}_{\text {water values (indicated on each curve) and variable }}$ temperatures. Horizontal dashed grey lines are calculated for fixed temperatures and variable $\delta^{18} \mathrm{O}_{\text {water. The average } \delta^{18} \mathrm{O}_{\text {water value }}}$ of $-6.6 \pm 0.4 \%$ measured in our experiments is reported using the thick solid grey curve. The solid black curve was obtained using the $\delta^{18} \mathrm{O}_{\text {water }}$ calculated with Eq. (2) $(-8.0 \pm 2.8 \%$ o with its associated errors (dashed black curves).

with $\delta^{18} \mathrm{O}_{\text {water }}$ and $\delta^{18} \mathrm{O}_{\text {carbonate }}$ values in the same isotopic reference (here VSMOW) and $\Delta_{47}$ values reported on the absolute carbon dioxide equilibrated scale $\left(\Delta_{47}\right.$ CDES 90$)$. The calibration of Kim and O'Neil (1997) was preferred over more recent calibration equations (e.g., Watkins et al., 2013) because it provides the best consistency for temperatures reconstructed from both the carbonate $\delta^{18} \mathrm{O}$ and $\Delta_{47}$ values at temperatures above $100^{\circ} \mathrm{C}$. Note that Kim and O'Neil (1997) and Bonifacie et al. (2017) calibrations were developed independently, which prevents circular reasoning. Finally, as the calibration of Kim and O'Neil (1997) is the most used calcite calibration to date, it also allows for a broader comparison with previously published results.

Despite the fact that the data present a large range of offsets from equilibrium (Fig. 5), the mean $\delta^{18} \mathrm{O}_{\text {water value }}$ calculated using Eq. (2) for each combination of $\Delta_{47}$ and $\delta^{18} \mathrm{O}_{\text {carbonate }}$ values measured for our carbonates is $-8.0 \pm$ $2.8 \%$ ( $1 \mathrm{SD}$ ), indistinguishable (i.e., within errors) from the $\delta^{18} \mathrm{O}_{\text {water }}$ values measured in our experiments $(-6.4 \pm 0.2 \%$ o with CA and $-6.8 \pm 0.2 \%$ without CA; Fig. 5). Note that such precision in $\delta^{18} \mathrm{O}_{\text {water }}$ values found in disequilibrium carbonates is remarkable considering that even for equilibrium carbonates at isotopic equilibrium for both $\delta^{13} \mathrm{C}$ and $\delta^{18} \mathrm{O}, \delta^{18} \mathrm{O}_{\text {water }}$ can only be retrieved from paired $\Delta_{47}$ and $\delta^{18} \mathrm{O}_{\text {carbonate }}$ values with a precision of $\pm 1 \%$ at best (see Fig. S1 in the Supplement). This creates the promising opportunity to retrieve the $\delta^{18} \mathrm{O}$ value of the water in which car- 
bonates precipitated out of equilibrium for both $\delta^{18} \mathrm{O}_{\text {carbonate }}$ and $\Delta_{47}$.

In order to evaluate the applicability of such an approach to other types of carbonates, Fig. 6 compiles disequilibrium paired $\delta^{18} \mathrm{O}_{\text {carbonate }}$ and $\Delta_{47}$ data from two previously published experimental studies (Tang et al., 2014; Staudigel and Swart, 2018). These studies were chosen to further evaluate the relevancy of our $\delta^{18} \mathrm{O}_{\text {carbonate }}-\Delta_{47}$ correlation because they are the only published dataset reporting full sets of measured (rather than calculated) $\delta^{18} \mathrm{O}_{\text {water }}, \delta^{18} \mathrm{O}_{\text {carbonate }}$ and $\Delta_{47}$ values, with one or both proxies showing disequilibrium, together with precipitation temperatures. A perfect knowledge (i.e., measurements and not estimates) of these four parameters is mandatory here to adequately test whether the use of our new $\delta^{18} \mathrm{O}_{\text {water }}$ proxy could be generalized to a large diversity of carbonates. This thus precludes plotting most published $\Delta_{47}$ studies on both natural and experimental samples, in which $\delta^{18} \mathrm{O}_{\text {water }}$ and/or temperature were not directly measured, in Fig. 6. These two datasets are also recent enough to allow the conversion of their $\Delta_{47}$ values to the currently used normalization method (i.e., the CDES absolute reference frame). It will then allow comparison with future studies, if measuring and reporting all these four parameters together becomes the rule rather than the exception in $\Delta_{47}$ studies.

Figure 6a shows paired $\delta^{18} \mathrm{O}_{\text {carbonate }}$ and $\Delta_{47}$ values of abiotic carbonates produced at 5,25 and $40^{\circ} \mathrm{C}$ that are known to be affected by KIF due to fast precipitation and for at least two of them by KIF due to $\mathrm{CO}_{2}$ hydration and hydroxylation prior to precipitation (Tang et al., 2014). Except for these two carbonate samples, the data align on a covariation curve of $\Delta_{47}$ versus $\delta^{18} \mathrm{O}_{\text {carbonate }}$ that cannot be explained solely by temperature variation. As for our microbial carbonates obtained with or without $\mathrm{CA}$, the average calculated $\delta^{18} \mathrm{O}_{\text {water }}$ (Eq. $2 ;-11.2 \pm 1.5 \%$ ) matches within error with the measured $\delta^{18} \mathrm{O}_{\text {water }}(-9.6 \pm 0.2 \%$ ) (Dietzel et al., 2009).

Figure $6 \mathrm{~b}$ shows paired $\delta^{18} \mathrm{O}_{\text {carbonate }}$ and $\Delta_{47}$ values of abiotic carbonates that were precipitated during an initial $\mathrm{CO}_{2}$ degassing + DIC equilibration phase followed by solely equilibration with water at 5,15 and $25^{\circ} \mathrm{C}$ (Staudigel and Swart, 2018). During the latter equilibration phase, even though the carbonates precipitated out of isotopic equilibrium, the paired $\delta^{18} \mathrm{O}_{\text {carbonate }}$ and $\Delta_{47}$ values align on a covariation curve of the average calculated $\delta^{18} \mathrm{O}_{\text {water }}$ value (Eq. $2 ;-3.0 \pm 1.1 \%$ ) close to the measured $\delta^{18} \mathrm{O}_{\text {water }}$ $(-0.65 \%$ o). As a major outcome of this study, we thus anticipate that reliable $\delta^{18} \mathrm{O}_{\text {water }}$ values of precipitation water can be retrieved from carbonates presenting $\Delta_{47}$ and $\delta^{18} \mathrm{O}_{\text {carbonate }}$ values in strong disequilibrium.

Some data presented in Fig. 6 also permit us to evaluate the conditions of applicability of our approach. In Fig. 6a, the two data points deviating from the covariation curve of $\Delta_{47}$ versus $\delta^{18} \mathrm{O}_{\text {carbonate }}$ correspond to carbonates precipitated at $\mathrm{pH} \sim 10$ and $5^{\circ} \mathrm{C}$ (while the others formed at $\mathrm{pH}$ and
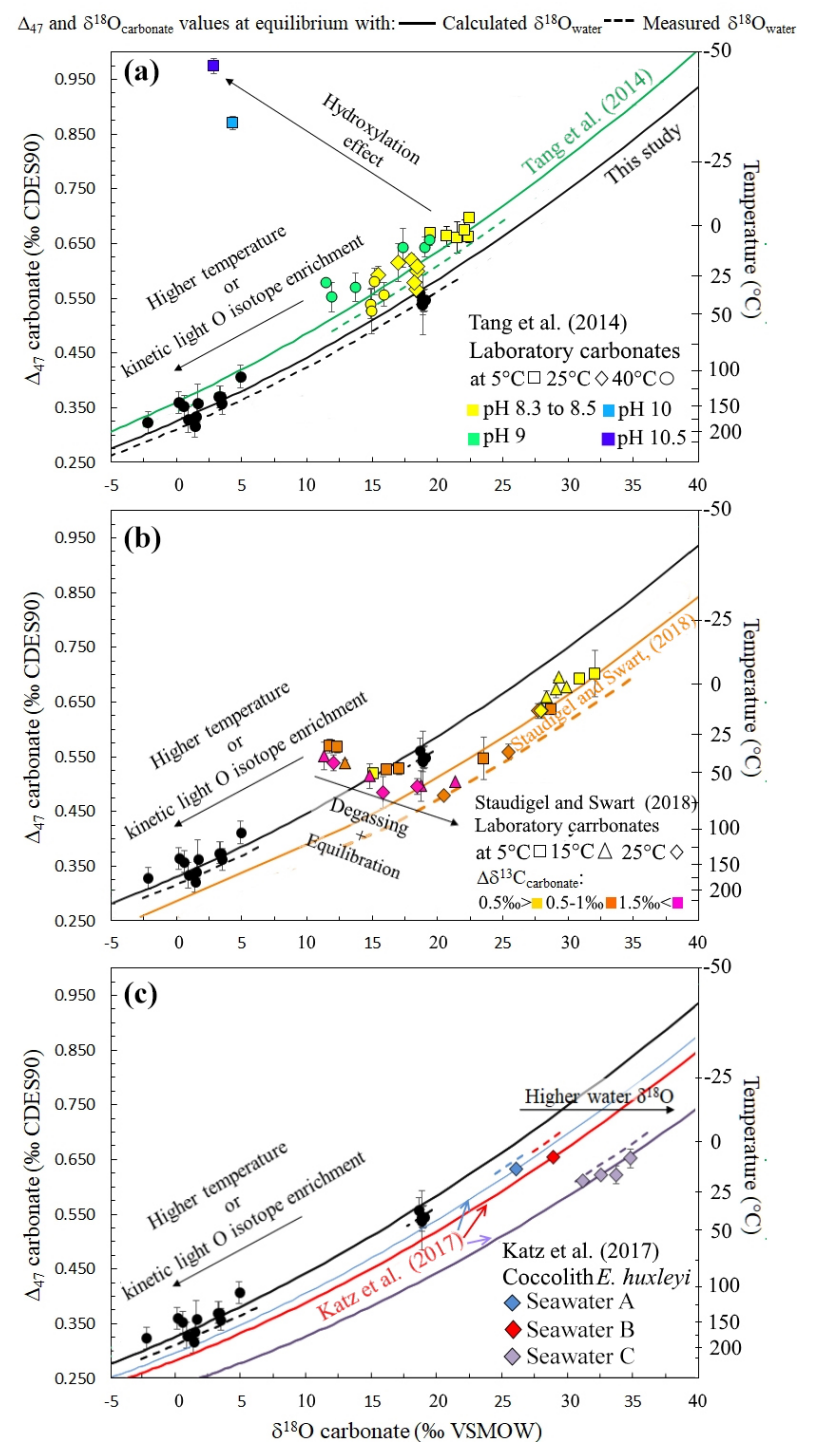

Figure 6. $\Delta_{47}$ and $\delta^{18} \mathrm{O}_{\text {carbonate }}$ relationship to precipitation water $\delta^{18} \mathrm{O}_{\text {water }}$ for other solid carbonates presenting oxygen isotope disequilibria. In (a) to (c) the black data series (this study, performed at $30^{\circ} \mathrm{C}$ ) shows how kinetic oxygen isotope fractionation in the DIC prior to carbonate precipitation can be mistaken for high-temperature isotopic equilibrium. Similarly to Fig. 5, the solid curves were obtained using the $\delta^{18} \mathrm{O}_{\text {water }}$ calculated with Eq. (2). (a) Abiotic carbonates from Tang et al. (2014) illustrating the effect of $\mathrm{CO}_{2}$ hydroxylation on $\Delta_{47}$ and $\delta^{18} \mathrm{O}_{\text {carbonate values (various }}$ $\mathrm{pH}$ values plotted with different colors, various temperatures plotted with different symbols). (b) Abiotic carbonates from Staudigel and Swart (2018) illustrating the effect of $\mathrm{CO}_{2}$ degassing and DIC oxygen isotope equilibration with water on $\Delta_{47}$ and $\delta^{18} \mathrm{O}_{\text {carbonate }}$ values. $\Delta \delta^{13} \mathrm{C}_{\text {carbonate }}$ stands for the difference between the $\delta^{13} \mathrm{C}$ value measured in carbonates and the final $\delta^{13} \mathrm{C}$ of the data series at the end of equilibration (various $\Delta \delta^{13} \mathrm{C}$ ranges plotted with different colors, various temperatures plotted with different symbols). (c) Coccolithophorid E. huxleyi grown at 7, 10, 15, 20 and $25^{\circ} \mathrm{C}$ from Katz et al. (2017) showing how coccoliths with equilibrium $\Delta_{47}$ values record the equilibrium $\delta^{18} \mathrm{O}_{\text {water }}$ of their body water, which differs from that of the culture medium (i.e., artificial seawaters A, B and C plotted with different colors). 
temperatures ranging from 8.3 to 9 and 5 to $40{ }^{\circ} \mathrm{C}$, respectively) that have recorded a KIF due to $\mathrm{CO}_{2}$ hydration and hydroxylation prior to precipitation (Tang et al., 2014). At $\mathrm{pH}=10, \mathrm{CO}_{2}$ reacts at $95 \%$ with $\mathrm{OH}^{-}$, and at $5^{\circ} \mathrm{C}$ DIC isotopic equilibration with water takes days. To a lesser extent, the KIF induced by $\mathrm{CO}_{2}$ hydroxylation also seems visible at $\mathrm{pH}=9$ (and $40^{\circ} \mathrm{C}$ ), where $\mathrm{CO}_{2}$ reacts at $82 \%$ with $\mathrm{OH}^{-}$, but DIC isotopic equilibration with water at $40^{\circ} \mathrm{C}$ only takes about $15 \mathrm{~h}$. As previously detailed, the direction of these isotopic offsets from equilibrium is compatible with ab initio calculations (Guo, 2009) and can be intuitively understood as follows: in carbonates derived from $\mathrm{CO}_{2}$ hydroxylation, the $R_{\text {stochastic }}^{X}$ term used for the $\Delta_{47}$ calculation (Eq. 1) should be strongly modified as the ${ }^{18} \mathrm{O}$ concentration in $\mathrm{OH}^{-}$and $\mathrm{H}_{2} \mathrm{O}$ is lower than in $\mathrm{CO}_{2}$, and the reaction does not add more ${ }^{13} \mathrm{C}$ than what is present in $\mathrm{CO}_{2}$. This might explain why in the case of disequilibria acquired through $\mathrm{CO}_{2}$ hydroxylation, the correlation between paired $\delta^{18} \mathrm{O}$ and $\Delta_{47}$ disequilibria and the precipitation water $\delta^{18} \mathrm{O}$ is not preserved, and $\delta^{18} \mathrm{O}_{\text {water }}$ cannot be reconstructed by the approach proposed here. The negative slope associated with this KIF on the $\Delta_{47}$ and $\delta^{18} \mathrm{O}_{\text {carbonate }}$ diagram (Fig. 6a) is nevertheless a good tool to identify $\mathrm{CO}_{2}$ hydroxylation reactions.

In Fig. 6b, during the $\mathrm{CO}_{2}$ degassing phase of the precipitation experiment (Staudigel and Swart, 2018), the data also deviate from the covariation curve of $\delta^{18} \mathrm{O}$ versus $\Delta_{47}$. This behavior was interpreted by the authors as a decoupling between $\Delta_{47}$ and $\delta^{18} \mathrm{O}_{\text {carbonate }}$ values due to variable kinetics of ${ }^{12} \mathrm{C}-\mathrm{O}$ and ${ }^{13} \mathrm{C}-\mathrm{O}$ bonding. A known difference in equilibration kinetics takes place between $\mathrm{C}$ and $\mathrm{O}$ isotopes in the carbonate system as carbon isotopes equilibrate in seconds, while oxygen isotopes necessitate minutes to hours to equilibrate among the different oxygen-bearing species (i.e., $\mathrm{CO}_{2}$, $\mathrm{HCO}_{3}^{-}, \mathrm{CO}_{3}^{2-}, \mathrm{H}_{2} \mathrm{O}, \mathrm{OH}^{-}$), depending on the $\mathrm{pH}$, temperature and salinity of the solution (Zeebe and Wolf-Gladrow, 2001). However, note that in that experiment, the carbon isotope compositions evolved for several hours as a result of $\mathrm{CO}_{2}$ degassing (Staudigel and Swart, 2018). We propose here that $\mathrm{CO}_{2}$ degassing, because it affects both $\mathrm{C}$ and $\mathrm{O}$ isotopes, modifies the $R_{\text {stochastic }}^{X}$ term (in Eq. 1), thus preventing $\Delta_{47}$ and $\delta^{18} \mathrm{O}$ from varying with the proportionality that allows

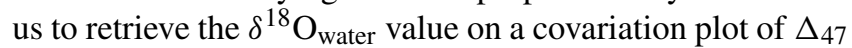
versus $\delta^{18} \mathrm{O}$. Hence, as for $\mathrm{CO}_{2}$ hydroxylation, in the case of a KIF induced by $\mathrm{CO}_{2}$ degassing, $\delta^{18} \mathrm{O}_{\text {water }}$ cannot be reconstructed exclusively from disequilibrium $\delta^{18} \mathrm{O}_{\text {carbonate }}$ and $\Delta_{47}$ values.

In summary, we conclude that mechanisms that can drastically change the $R_{\text {stochastic }}^{X}$ term in $\Delta_{47}$ calculation (such as $\mathrm{CO}_{2}$ hydroxylation and degassing) prevent $\delta^{18} \mathrm{O}_{\text {water }}$ reconstructions from paired disequilibrium $\Delta_{47}$ and $\delta^{18} \mathrm{O}_{\text {carbonate }}$ values. Nevertheless, these mechanisms lead to peculiar types of carbonates (e.g., speleothems that form in caves from $\mathrm{CO}_{2}$ degassing, and travertine that forms on lands where fluids and gas escape from subsurface reservoirs, for $\mathrm{CO}_{2}$ hydroxylation) that represent only a small fraction of all the carbonates existing on Earth. We hypothesize that ureolysis, which consists in two successive steps of urea hydrolysis, an exchange reaction with the $\mathrm{H}_{2} \mathrm{O}$ molecule from the aqueous medium, might give a DIC whose $R_{\text {stochastic }}^{X}$ term in the $\Delta_{47}$ calculation is already close to that of DIC under equilibration with the $\delta^{18} \mathrm{O}_{\text {water. This would explain why even our }}$ most extreme out-of-equilibrium carbonates still fall close to the covariation line of $\Delta_{47}$ versus $\delta^{18} \mathrm{O}_{\text {carbonate }}$ corresponding to the real $\delta^{18} \mathrm{O}_{\text {water value. }}$

\subsection{Toward a better understanding of body water $\delta^{18} \mathrm{O}$ in biomineralizing organisms}

The ability to reconstruct precipitation water $\delta^{18} \mathrm{O}_{\text {water }}$ from disequilibrium $\Delta_{47}$ and $\delta^{18} \mathrm{O}_{\text {carbonate values further allows }}$ us to examine the origin of the vital effect observed in organisms for which (i) $\mathrm{CO}_{2}$ degassing and hydration and hydroxylation KIF can be ruled out, and (ii) only small $\delta^{13} \mathrm{C}$ variations are observed, thus preserving the $R_{\text {stochastic }}^{X}$ term in $\Delta_{47}$ calculation. We hypothesize that such an approach could help to understand how $\Delta_{47}$ and $\delta^{18} \mathrm{O}$ signals are affected by kinetic effects in most of the biogenic carbonates, provided that $\mathrm{CO}_{2}$ hydroxylation or degassing does not occur prior to carbonate precipitation. This approach could thus be applied to the vast majority of sedimentary carbonates (Milliman, 1993) (i.e., microbialites, brachiopods, bryozoans, bivalves, foraminifera, coccoliths) and since deep time, even

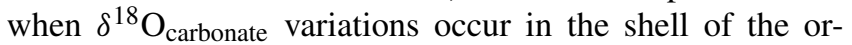
ganism. Additionally, the data presented here stand as an experimental demonstration that the mechanisms controlling carbonate $\delta^{18} \mathrm{O}$ equilibration with water (i.e., DIC equilibration with water) also control solid carbonate $\Delta_{47}$ equilibrium (Watkins and Hunt, 2015). This result can be used to recover information on biomineralization mechanisms. For example, in recent coccolithophorid Emiliania huxleyi culture experiments, the calcitic shell produced by the organism systematically yields a $2 \%$ positive $\delta^{18} \mathrm{O}$ offset from equilibrium values while its $\Delta_{47}$ values seem to faithfully record precipitation temperature (Katz et al., 2017). These coccolithophorids were grown in waters with different $\delta^{18} \mathrm{O}_{\text {water }}$ compositions (i.e., measured at $-6.14 \%$, $-5.82 \%$ and $0.65 \%$ VSMOW that are respectively seawater A, B and $\mathrm{C}$ in Fig. 6c). Based on our results, which demonstrate that no $\delta^{18} \mathrm{O}$ disequilibrium should be recorded in solid carbonates if the associated $\Delta_{47}$ is at equilibrium, we can assume that the coccoliths precipitated at oxygen isotope equilibrium. We also calculate the actual $\delta^{18} \mathrm{O}$ value of the water in which precipitation took place from Eq. (2) (respectively shifted by $1.0 \pm 0.2 \% \circ, 2.1 \pm 0.4 \% \circ$ and $1.1 \pm 0.7 \%$ o towards more positive values compared to the $\delta^{18} \mathrm{O}_{\text {water value measured for }}$ the culture medium water; Fig. 6c). This could reflect a biologically driven difference between the $\delta^{18} \mathrm{O}$ of body water at the precipitation site inside E. huxleyi and the $\delta^{18} \mathrm{O}$ of ambient water (i.e., the culture medium water). This hypothesis is supported by what is known about intracellular 
precipitation of coccoliths performed by coccolithophorids: each coccolith forms from the accumulation of coccolithosomes, which are vesicles containing up to approximately twelve $7 \mathrm{~nm}$ spherical calcium-rich granular units (Outka and Williams, 1971). Water in these $\sim 100 \mathrm{~nm}$ vesicles can be considered a finite reservoir whose isotopic composition could be modified through isotopic exchange with DIC affected by metabolic isotope fractionation. Another mechanism that could increase the $\delta^{18} \mathrm{O}$ value of a finite water reservoir by equilibrating it with a comparable reservoir of DIC would be the introduction of DIC systematically as $\mathrm{CO}_{2}$. As $\mathrm{HCO}_{3}^{-}$and $\mathrm{CO}_{3}^{2-}$ are enriched in ${ }^{16} \mathrm{O}$ in comparison to $\mathrm{CO}_{2}$, the $\mathrm{CO}_{2}$ conversion to $\mathrm{HCO}_{3}^{-}$and $\mathrm{CO}_{3}^{2-}$ at equilibrium before precipitation would pump ${ }^{16} \mathrm{O}$ from water.

In both case scenarios, a local change in water isotopic composition requires that the water molecules' turnover (i.e., external inputs) in these cellular organites is slow enough. Coccolithosomes are subunits of the Golgi complex, which is a system of flat stacked vesicles concentrating a lot of membranes in a small location (Outka and Williams, 1971). It is thus plausible that in a single-celled organism, living in seawater and performing intracellular biomineralization, specific osmolarity and water circulation regulation mechanisms are occurring. It is particularly plausible in the Golgi complex, whose water content is isolated from seawater by several membranes. We thus suggest that inside coccolithosomes, coccolith precursors precipitate in equilibrium with the body water for oxygen isotopes but that the body water has a different $\delta^{18} \mathrm{O}$ value than the seawater, which explains the observed $\delta^{18} \mathrm{O}$ apparent fractionation while the $\Delta_{47}$ composition reflects culture temperature (Katz et al., 2017). It has already been highlighted through geochemical analysis of coccoliths that coccolithosome water has altered $\mathrm{pH}$ (Liu et al., 2018) and ion concentrations (Hermoso et al., 2017) in comparison to seawater. We hypothesize that the internal $\delta^{18} \mathrm{O}$ water would thus be another parameter controlled by the coccolithophore algae.

\subsection{Ubiquity of the observed $\delta^{18} O_{\text {carbonate }}-\delta^{18} O_{\text {water }}-\Delta_{47}$-temperature covariations in both equilibrium and disequilibrium carbonates}

As shown above (Fig. 5), in a diagram of $\Delta_{47}$ versus $\delta^{18} \mathrm{O}_{\text {carbonate, }}$, disequilibrium carbonates precipitated at fixed temperature plot on the theoretical line of equilibrium carbonates precipitated with a similar $\delta^{18} \mathrm{O}_{\text {water }}$ but at a different temperature. This is illustrated in Fig. 7 where the three disequilibrium data series studied in this paper (Fig. 5 for this study and Fig. 6a and b for datasets from Tang et al., 2014, and Staudigel and Swart, 2018) align with equilibrium data series. In other words, the values of the disequilibrium $1000 \ln \alpha_{\text {carbonate-water }}$ for oxygen isotopes (with $\alpha=\frac{\delta^{18} \mathrm{O}_{\text {carbonate }}+1000}{\delta^{18} \mathrm{O}_{\text {water }}+1000}$ ) are similar to the equilibrium

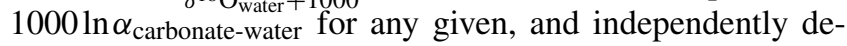

termined, apparent $\Delta_{47}$ temperature (Fig. 7). In detail, our closest-to-equilibrium data recording low apparent temperatures match better with the predicted equations from Coplen (2007) and Watkins et al. (2013), recently updated (Daëron et al., 2019). This last calibration is based on carbonates from two caves where calcite precipitates extremely slowly and is thus assumed to have precipitated at equilibrium. Note that the use of these two cave samples for determining the dependence on temperature of the equilibrium $1000 \ln \alpha_{\text {carbonate-water }}$ relies on the assumption that constant environmental conditions, including temperature in the two caves $\left(7.9\right.$ and $\left.33.7^{\circ} \mathrm{C}\right)$ and the $\delta^{18} \mathrm{O}_{\text {water value of the pre- }}$ cipitation water, prevailed over the whole period of carbonate precipitation (Coplen, 2007; Kluge et al., 2014). In Fig. 7, the disequilibrium data recording high apparent temperatures (above $100^{\circ} \mathrm{C}$ ) match better with the predicted equation of Kim and O'Neil (1997). This $1000 \ln \alpha_{\text {carbonate-water depen- }}$ dence on temperature was established on carbonates precipitated in the laboratory at well-known $\delta^{18} \mathrm{O}_{\text {water }}$ and temperatures (from 10 to $40^{\circ} \mathrm{C}$ ) but was suspected to present a small KIF due to a high precipitation rate that lowers the value of the $1000 \ln \alpha_{\text {carbonate-water }}$ (Watkins et al., 2013). Despite this, we used this equation to retrieve the $\delta^{18} \mathrm{O}_{\text {water }}$ from our experimental carbonates, because most of them are associated with high apparent $\Delta_{47}$ temperatures. Coplen (2007) or Watkins et al. (2013) equations would have $2 \%$ lower values (ca. $-10 \pm 2 \%$ o compared to $-8 \pm 3 \%$ o calculated with the equation of Kim and O'Neil, 1997). From our results, due to our experimental conditions and the associated error in our dataset, it is not possible and not our intention to argue in favor of one of these calibrations. This however shows how crucial it is to improve knowledge on the equilibrium

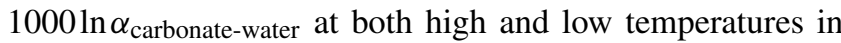
order to improve the accuracy and precision of our new proxy for reconstructing the $\delta^{18} \mathrm{O}_{\text {water }}$ from which carbonates, even disequilibrium ones, precipitated.

Importantly, we here establish a new method to determine the equilibrium $1000 \ln \alpha_{\text {carbonate-water, which consists }}$ in using the kinetics of $\Delta_{47}$ and $\delta^{18} \mathrm{O}$ covariations during (dis)equilibration. Notably, because of the very large range of apparent temperatures recorded by disequilibrium carbonates (between $\sim 40$ and $200^{\circ} \mathrm{C}$; Fig. 7), this method could be particularly adapted to calibrate $1000 \ln \alpha_{\text {carbonate-water }}$ at high temperatures for which the differences between the two most popular equations for $1000 \ln \alpha_{\text {carbonate-water dependence on }}$ temperature (Kim and O'Neil, 1997; Coplen, 2007) appear larger (Fig. 7). Unfortunately, none of the three experimental setups having produced these disequilibrium carbonates (this study, as well as Tang et al., 2014, and Staudigel and Swart, 2018) were designed for the purpose of calibrating

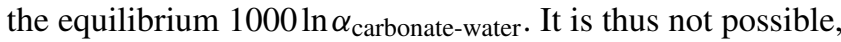
using these datasets, to propose a meaningful calibration. At least in our experiment, too many phenomena including the relatively high precipitation rate, variations in $\delta^{13} \mathrm{C}$ values $(\sim 3 \%$ o) (Thaler et al., 2017$)$ and presence of traces of arag- 


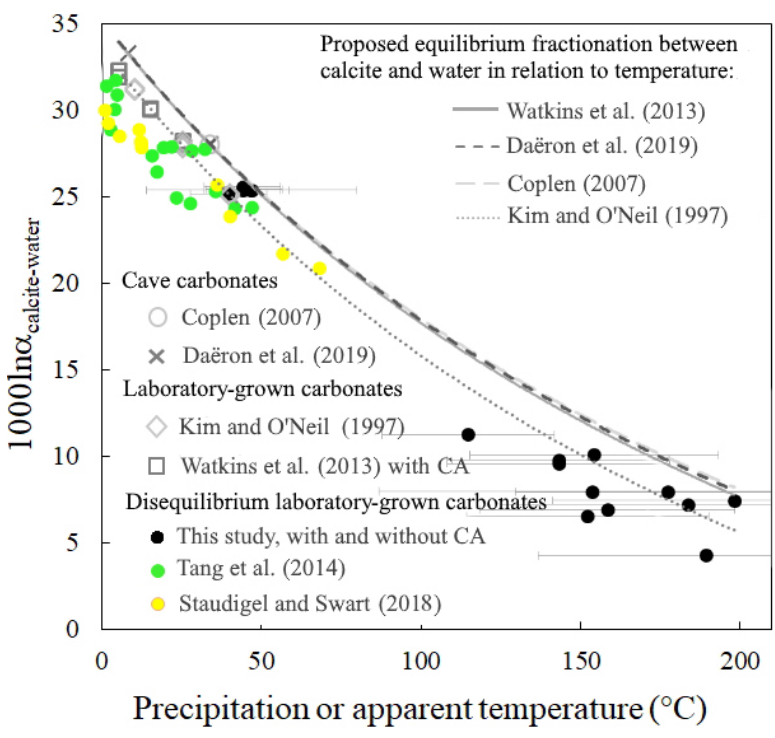

Figure 7. The relation to temperature of the equilibrium oxygen isotope fractionation factor between calcium carbonate and water ( $\left.1000 \ln \alpha_{\text {calcite-water }}\right)$ appears to be retrievable from solid carbonates (mainly calcites) in strong clumped and oxygen isotope disequilibrium such as our microbial carbonates (black dots, precipitated at $30^{\circ} \mathrm{C}$ ) and two additional data series of laboratory-grown carbonates showing disequilibrium fractionation (Tang et al., 2014; Staudigel and Swart, 2018) (green and yellow dots, respectively). The data points affected by $\mathrm{CO}_{2}$ hydroxylation (Tang et al., 2014) or $\mathrm{CO}_{2}$ degassing (Staudigel and Swart, 2018) (see Fig. 6) are not included. Grey symbols correspond to cave carbonates precipitated at or near equilibrium (Coplen, 2007; Daëron et al., 2019) or laboratory experiments (Kim and O'Neil, 1997; Watkins et al., 2013). Those grey data series are usually considered representative of the equilibrium fractionation factor between calcium carbonate and water whose relations to temperature, extrapolated at high temperature, are illustrated by the different dashed curves. Plotted temperatures correspond to precipitation temperatures except for disequilibrium carbonates for which apparent temperatures have been calculated based on $\Delta_{47}$ values. The $x$-axis errors for this study are included in the symbol size. The $y$-axis error for all the reconstructed temperatures is given on the figure.

onite and vaterite in our carbonates (Sect. 2.1 and Sect. S1 in the Supplement) lower the accuracy of the reconstructed equilibrium $1000 \ln \alpha_{\text {carbonate-water values. }}$

From a broader perspective, we anticipate that such an approach will help in determining critical equilibrium fractionation factors for other gaseous isotopic systems (such as isotopologues of molecules containing $\mathrm{S}-\mathrm{O}$ bonds) or minerals of prime interest in biology and geology if clumped isotope measurements expand further beyond gaseous mass spectrometry (e.g., bonding between $\mathrm{Fe}-\mathrm{O}, \mathrm{Fe}-\mathrm{S}, \mathrm{Ca}-\mathrm{C}$ ).

\section{Conclusions}

Our experimental results show that the information held in disequilibrium (and apparent disequilibrium) carbonates is diverse and promising. First, a paired $\Delta_{47}$ and $\delta^{18} \mathrm{O}_{\text {carbonate }}$ disequilibrium indicates that carbonates have precipitated in a dynamic environment where DIC and water did not reach isotopic equilibrium. In our microbial carbonate experiments, all the DIC is produced in isotopic disequilibrium with water and precipitates rapidly. Accordingly, the disequilibrium $\mathrm{O}$ isotope compositions recorded in those carbonates are maximized compared to what can be expected in nature where newly produced DIC is expected to be mixed with at least partly equilibrated ambient DIC before carbonates precipitate. Second, the combined use of clumped and traditional oxygen isotopic compositions allows the retrieval of the $\delta^{18} \mathrm{O}$ of the precipitation water, i.e., organism body water or environmental water, even for carbonates presenting $\delta^{18} \mathrm{O}$ and/or $\Delta_{47}$ disequilibria or apparent disequilibria. Hence, except in the case of processes such as $\mathrm{CO}_{2}$ degassing and $\mathrm{CO}_{2}$ hydration and hydroxylation, which likely modify the $R_{\text {stochastic }}^{X}$ term in $\Delta_{47}$ calculation, paired $\Delta_{47}$ and $\delta^{18} \mathrm{O}_{\text {carbonates }}$ disequilibria in carbonates can be used to reconstruct the oxygen isotope composition of both DIC and water at the precipitation loci even when precipitation occurred under disequilibrium conditions. Third, the (dis)equilibration trend in a covariation diagram of $\Delta_{47}$ versus $\delta^{18} \mathrm{O}_{\text {carbonates }}$ can be used as a new method to determine the equilibrium fractionation factor between carbonate and water for a wide range of temperatures. Altogether, this opens up new avenues to better constrain not only past climate changes through improved paleoenvironmental reconstructions but also the physiology and habitat of sea life sensitive to ocean acidification.

Data availability. All the data generated and analyzed in this study are available within the paper and in its Supplement.

Supplement. The supplement related to this article is available online at: https://doi.org/10.5194/bg-17-1731-2020-supplement.

Author contributions. CT and AK conceived the research. CT performed the microbial precipitation experiment and the $\delta^{13} \mathrm{C}$ and $\delta^{18} \mathrm{O}$ analyses during her $\mathrm{PhD}$ thesis under the supervision of MA and BM. AK performed the $\Delta_{47}$ analyses during her PhD thesis under MB's supervision. CT took the lead in the interpretation of the results and the writing of the original draft. All authors provided critical feedback and helped shape the research, analyses and manuscript.

Competing interests. The authors declare that they have no conflict of interest. 
Acknowledgements. This research was supported by French MRT $\mathrm{PhD}$ fellowships to Caroline Thaler and Amandine Katz, the Centre de Recherches sur le Stockage Géologique du $\mathrm{CO}_{2}$ (IPGP-TOTALSchlumberger-ADEME) (Bénédicte Ménez and Magali Ader), and an Emergence program grant from the Paris council to Magali Bonifacie. The authors are grateful for the insightful reviews of William F. Defliese and Stefano M. Bernasconi that improved the manuscript. This study contributes to the IdEx Université de Paris ANR-18-IDEX-0001.

Financial support. This research has been supported by French MRT PhD fellowships to Caroline Thaler and Amandine Katz, the Centre de Recherches sur le Stockage Géologique du $\mathrm{CO}_{2}$ (IPGPTOTAL-Schlumberger-ADEME) (Bénédicte Ménez and Magali Ader), and an Emergence program grant from the Paris council to Magali Bonifacie.

Review statement. This paper was edited by Carolin Löscher and reviewed by William Defliese and Stefano Bernasconi.

\section{References}

Affek, H. P., Bar-Matthews, M., Ayalon, A., Matthews, A., and Eiler, J. M.: Glacial/interglacial temperature variations in Soreq cave speleothems as recorded by "clumped isotope" thermometry, Geochim. Cosmochim. Ac., 72, 5351-5360, https://doi.org/10.1016/j.gca.2008.06.031, 2008.

Affek, H. P.: Clumped isotopic equilibrium and the rate of isotope exchange between $\mathrm{CO}_{2}$ and water, Am. J. Sci., 313, 309-325, https://doi.org/10.2475/04.2013.02, 2013.

Affek, H. P. and Zaarur, S.: Kinetic isotope effect in $\mathrm{CO}_{2}$ degassing: Insight from clumped and oxygen isotopes in laboratory precipitation experiments, Geochim. Cosmochim. Ac., 143, 319-330, https://doi.org/10.1016/j.gca.2014.08.005, 2014.

Affek, H. P., Matthews, A., Ayalon, A., Bar-Matthews, M., Burstyn, Y., Zaarur, S., and Zilberman, T.: Accounting for kinetic isotope effects in Soreq Cave (Israel) speleothems, Geochim. Cosmochim. Ac., 143, 303-318, https://doi.org/10.1016/j.gca.2014.08.008, 2014.

Bajnai, D., Fiebig, J., Tomašových, A., Garcia, S. M., Rollion-Bard, C., Raddatz, J., Löffler, N., Primo-Ramos, C., and Brand, U.: Assessing kinetic fractionation in brachiopod calcite using clumped isotopes, Sci. Rep.-UK, 8, 533, https://doi.org/10.1038/s41598017-17353-7, 2018.

Beck, W. C., Grossman, E. L., and Morse, J. W.: Experimental studies of oxygen isotope fractionation in the carbonic acid system at 15,25 , and $40^{\circ} \mathrm{C}$, Geochim. Cosmochim. Ac., 69, 3493-3503, https://doi.org/10.1016/j.gca.2005.02.003, 2005.

Bernasconi, S. M., Müller, I. A., Bergmann, K. D., Breitenbach, S. F., Fernandez, A., Hodell, D. A., Jaggi, M., Meckler, A. N., Millan, I., and Ziegler, M.: Reducing uncertainties in carbonate clumped isotope analysis through consistent carbonatebased standardization, Geochem. Geophy. Geosy., 19, 28952914, https://doi.org/10.1029/2017GC007385, 2018.

Bonifacie, M., Calmels, D., Eiler, J. M., Horita, J., Chaduteau, C., Vasconcelos, C., Agrinier, P., Katz, A., Passey, B.
H., Ferry, J. M., and Bourrand, J. J.: Calibration of the dolomite clumped isotope thermometer from 25 to $350{ }^{\circ} \mathrm{C}$, and implications for a universal calibration for all $(\mathrm{Ca}, \mathrm{Mg}$, $\mathrm{Fe}) \mathrm{CO}_{3}$ carbonates, Geochim. Cosmochim. Ac., 200, 255-279, https://doi.org/10.1016/j.gca.2016.11.028, 2017.

Brand, W. A., Assonov, S. S., and Coplen, T. B.: Correction for the ${ }^{17} \mathrm{O}$ interference in $\delta^{13} \mathrm{C}$ measurements when analyzing $\mathrm{CO}_{2}$ with stable isotope mass spectrometry (IUPAC Technical Report), Pure Appl. Chem., 82, 1719-1733, https://doi.org/10.1351/PAC-REP-09-01-05, 2010.

Burgener, L. K., Huntington, K. W., Sletten, R., Watkins, J. M., Quade, J., and Hallet, B.: Clumped isotope constraints on equilibrium carbonate formation and kinetic isotope effects in freezing soils, Geochim. Cosmochim. Ac., 235, 402-430, https://doi.org/10.1016/j.gca.2018.06.006, 2018.

Clark, I. D., Fontes, J. C., and Fritz, P.: Stable isotope disequilibria in travertine from high $\mathrm{pH}$ waters: laboratory investigations and field observations from Oman, Geochim. Cosmochim. Ac., 56, 2041-2050, https://doi.org/10.1016/0016-7037(92)90328-G, 1992.

Clog, M., Stolper, D., and Eiler, J. M.: Kinetics of $\mathrm{CO}_{2}(\mathrm{~g})-\mathrm{H}_{2} \mathrm{O}(1)$ isotopic exchange, including mass 47 isotopologues, Chem. Geol., 395, 1-10, https://doi.org/10.1016/j.chemgeo.2014.11.023, 2015.

Coplen, T. B.: Calibration of the calcite-water oxygenisotope geothermometer at Devils Hole, Nevada, a natural laboratory, Geochim. Cosmochim. Ac., 71, 3948-3957, https://doi.org/10.1016/j.gca.2007.05.028, 2007.

Daëron, M., Blamart, D., Peral, M., and Affek, H. P.: Absolute isotopic abundance ratios and the accuracy of $\Delta_{47}$ measurements, Chem. Geol., 442, 83-96, https://doi.org/10.1016/j.chemgeo.2016.08.014, 2016.

Daëron, M., Drysdale, R. N., Peral, M., Huyghe, D., Blamart, D., Coplen, T. B., Lartaud, F., and Zanchetta, G.: Most Earth-surface calcites precipitate out of isotopic equilibrium, Nat. Commun., 10, 429, https://doi.org/10.1038/s41467-019-08336-5, 2019.

Dassié, E., Genty, D., Noret, A., Mangenot, X., Massault, M., Lebas, N., Duhamel, M., Bonifacie, M., Gasparrini, M., Minster, B., and Michelot, J. L.: A newly designed analytical line to examine the reproducibility of fluid inclusion isotopic compositions in small carbonate samples, Geochem. Geophy. Geosy., 19, 1107-1122, https://doi.org/10.1002/2017GC007289, 2018.

Dennis, K. J., Affek, H. P., and Schrag, D.: Defining an absolute reference frame for "clumped" isotope studies of $\mathrm{CO}_{2}$, Geochim. Cosmochim. Ac., 75, 7117-7131, https://doi.org/10.1016/j.gca.2011.09.025, 2011.

Dietzel, M., Tang, J., Leis, A., and Köhler, S. J.: Oxygen isotopic fractionation during inorganic calcite precipitation - Effects of temperature, precipitation rate and $\mathrm{pH}$, Chem. Geol., 268, 107115, https://doi.org/10.1016/j.chemgeo.2009.07.015, 2009.

Eiler, J. M.: Paleoclimate reconstruction using carbonate clumped isotope thermometry, Quaternary. Sci. Rev., 30, 3575-3588, https://doi.org/10.1016/j.quascirev.2011.09.001, 2011.

Falk, E. S., Guo, W., Paukert, A. N., Matter, J. M., Mervine, E. M., and Kelemen, P. B.: Controls on the stable isotope compositions of travertine from hyperalkaline springs in Oman: Insights from clumped isotope measurements, Geochim. Cosmochim. Ac., 192, 1-28, https://doi.org/10.1016/j.gca.2016.06.026, 2016. 
Fernandez, A., Müller, I. A., Rodríguez-Sanz, L., van Dijk, J., Looser, N., and Bernasconi, S. M.: A reassessment of the precision of carbonate clumped isotope measurements: Implications for calibrations and paleoclimate reconstructions, Geochem. Geophy. Geosy., 18, 4375-4386, https://doi.org/10.1002/2017GC007106, 2017.

Fiebig, J., Bajnai, D., Löffler, N., Methner, K., Krsnik, E., Mulch, A., and Hofmann, S.: Combined high-precision $\Delta^{48}$ and $\Delta^{47}$ analysis of carbonates, Chem. Geol., 522, 186-191, https://doi.org/10.1016/j.chemgeo.2019.05.019, 2019.

Ghosh, P., Adkins, J., Affek, H., Balta, B., Guo, W., Schauble, E., Schrag, D., and Eiler, J.: ${ }^{13} \mathrm{C}-{ }^{18} \mathrm{O}$ bonds in carbonate minerals: a new kind of paleothermometer, Geochim. Cosmochim. Ac., 70, 1439-1456, https://doi.org/10.1016/j.gca.2005.11.014, 2006.

Green, M. and Taube, H.: Isotopic fractionation in the $\mathrm{OH}-$ $\mathrm{H}_{2} \mathrm{O}$ exchange reaction, J. Phys. Chem., 67, 1565-1566, https://doi.org/10.1021/j100801a507, 1963.

Guo, W.: Carbonate clumped isotope thermometry: application to carbonaceous chondrites and effects of kinetic isotope fractionation, $\mathrm{PhD}$ thesis, California Institute of Technology, 261 pp., 2009.

Guo, W., Mosenfelder, J. L., Goddard III, W. A., and Eiler, J. M.: Isotopic fractionations associated with phosphoric acid digestion of carbonate minerals: insights from first principles theoretical modeling and clumped isotope measurements, Geochim. Cosmichim. Ac., 73, 7203-7225, https://doi.org/10.1016/j.gca.2009.05.071, 2009.

Henkes, G. A., Passey, B. H., Grossman, E. L., Shenton, B. J., Yancey, T. E., and Pérez-Huerta, A.: Temperature evolution and the oxygen isotope composition of Phanerozoic oceans from carbonate clumped isotope thermometry, Earth Planet. Sc. Lett., 490, 40-50, https://doi.org/10.1016/j.epsl.2018.02.001, 2018.

Hermoso, M., Lefeuvre, B., Minoletti, F., and de Rafélis, M.: Extreme strontium concentrations reveal specific biomineralization pathways in certain coccolithophores with implications for the $\mathrm{Sr} / \mathrm{Ca}$ paleoproductivity proxy, PLoS ONE, 12, e0185655, https://doi.org/10.1371/journal.pone.0185655, 2017.

Katz, A., Bonifacie, M., Hermoso, M., Cartigny, P., and Calmels, D.: Laboratory-grown coccoliths exhibit no vital effect in clumped isotope $\left(\Delta_{47}\right)$ composition on a range of geologically relevant temperatures, Geochim. Cosmochim. Ac., 208, 335353, https://doi.org/10.1016/j.gca.2017.02.025, 2017.

Kelson, J. R., Huntington, K. W., Schauer, A. J., Saenger, C., and Lechler, A. R.: Toward a universal carbonate clumped isotope calibration: Diverse synthesis and preparatory methods suggest a single temperature relationship, Geochim. Cosmochim. Ac., 197, 104-131, https://doi.org/10.1016/j.gca.2016.10.010, 2017.

Kim, S. T. and O'Neil, J. R.: Equilibrium and nonequilibrium oxygen isotope effects in synthetic carbonates, Geochim. Cosmochim. Ac., 61, 3461-3475, https://doi.org/10.1016/S00167037(97)00169-5, 1997.

Kluge, T., Affek, H. P., Dublyansky, Y., and Spötl, C.: Devils Hole paleotemperatures and implications for oxygen isotope equilibrium fractionation, Earth Planet. Sc. Lett., 400, 251-260, https://doi.org/10.1016/j.epsl.2014.05.047, 2014.

Krajewska, B.: Ureases I. Functional, catalytic and kinetic properties: A review, J. Mol. Catal. B-Enzym., 59, 9-21, https://doi.org/10.1016/j.molcatb.2009.01.003, 2009.
Krebs, H. A. and Roughton, F. J. W.: Carbonic anhydrase as a tool in studying the mechanism of reactions involving $\mathrm{H}_{2} \mathrm{CO}_{3}, \mathrm{CO}_{2}$ or $\mathrm{HCO}_{3}^{-}$, Biochem. J., 43, 550, https://doi.org/10.1042/bj0430550, 1948.

Létolle, R., Gegout, P., Gaveau, B., and Moranville-Regourd, M.: Isotope fractionation of ${ }^{18} \mathrm{O}$ during precipitation of carbonates at very high pH, CR Acad. Sci. II, 310, 547-552, 1990.

Liu, Y. W., Eagle, R. A., Aciego, S. M., Gilmore, R. E., and Ries, J. B.: A coastal coccolithophore maintains $\mathrm{pH}$ homeostasis and switches carbon sources in response to ocean acidification, Nat. Commun., 9, 2857, https://doi.org/10.1038/s41467-018-044637, 2018.

Loyd, S. J., Sample, J., Tripati, R. E., Defliese, W. F., Brooks, K., Hovland, T. M., Marlow, J., Hancock, L. G., Martin, R., and Lyons, T.: Methane seep carbonates yield clumped isotope signatures out of equilibrium with formation temperatures, Nat. Commun., 7, 12274, https://doi.org/10.1038/ncomms12274, 2016.

Mangenot, X., Bonifacie, M., Gasparrini, M., Götz, A., Chaduteau, C., Ader, M., and Rouchon, V.: Coupling $\Delta_{47}$ and fluid inclusion thermometry on carbonate cements to precisely reconstruct the temperature, salinity and $\delta^{18} \mathrm{O}$ of paleogroundwater in sedimentary basins, Chem. Geol., 472, 44-57, https://doi.org/10.1016/j.chemgeo.2017.10.011, 2017.

Mangenot, X., Gasparrini, M., Rouchon, V., and Bonifacie, M.: Basin-scale thermal and fluid-flow histories revealed by clumped isotope $\left(\Delta_{47}\right)$ - Middle Jurassic reservoirs of the Paris Basin, Sedimentology, 65, 123-150, https://doi.org/10.1111/sed.12427, 2018a.

Mangenot, X., Gerdes, A., Gasparrini, M., Bonifacie, M., and Rouchon, V.: An emerging thermo-chronometer for carbonate-bearing rocks: $\Delta^{47} /(\mathrm{U}-\mathrm{Pb})$, Geology, 46, 1067-1070, https://doi.org/10.1130/G45196.1, 2018b.

Matsuzaki, Y., Yamada, H., Chowdhury, F. A., Higashii, T., Kazama, S., and Onoda, M.: Ab initio study of $\mathrm{CO}_{2}$ capture mechanisms in monoethanolamine aqueous solution: reaction pathways from carbamate to bicarbonate, Enrgy. Proced., 37, 400-406, https://doi.org/10.1016/j.egypro.2013.05.124, 2013.

Milliman, J. D.: Production and accumulation of calcium carbonate in the ocean: budget of a nonsteady state, Global Biogeochem. Cy., 7, 927-957, https://doi.org/10.1029/93GB02524, 1993.

Millo, C., Dupraz, S., Ader, M., Guyot, F., Thaler, C., Foy, E., and Ménez, B.: Carbon isotope fractionation during calcium carbonate precipitation induced by ureolytic bacteria, Geochim. Cosmochim. Ac., 98, 107-124, https://doi.org/10.1016/j.gca.2012.08.029, 2012.

Mobley, H. L. and Hausinger, R. P.: Microbial ureases: significance, regulation, and molecular characterization, Microbiol. Mol. Biol. R., 53, 85-108, 1989.

Outka, D. E. and Williams, D. C.: Sequential coccolith morphogenesis in Hymenomonas carterae, J. Protozool., 18, 285-297, https://doi.org/10.1111/j.1550-7408.1971.tb03319.x, 1971.

Rollion-Bard, C., Chaussidon, M., and France-Lanord, C.: pH control on oxygen isotopic composition of symbiotic corals, Earth Planet. Sc. Lett., 215, 275-288, https://doi.org/10.1016/S0012821X(03)00391-1, 2003.

Saenger, C., Affek, H. P., Felis, T., Thiagarajan, N., Lough, J. M., and Holcomb, M.: Carbonate clumped isotope variability in shallow water corals: Temperature dependence and growth- 
related vital effects, Geochim. Cosmochim. Ac., 99, 224-242, https://doi.org/10.1016/j.gca.2012.09.035, 2012.

Schauer, A. J., Kelson, J. R., Saenger, C., and Huntington, K. W.: Choice of ${ }^{17} \mathrm{O}$ correction affects clumped isotope $\left(\Delta_{47}\right)$ values of $\mathrm{CO}_{2}$ measured with mass spectrometry, Rapid Commun. Mass Sp., 30, 2607-2616, https://doi.org/10.1002/rcm.7743, 2016.

Spooner, P. T., Guo, W., Robinson, L. F., Thiagarajan, N., Hendry, K. R., Rosenheim, B. E., and Leng, M. J.: Clumped isotope composition of cold-water corals: A role for vital effects?, Geochim. Cosmochim. Ac., 179, 123-141, https://doi.org/10.1016/j.gca.2016.01.023, 2016.

Staudigel, P. T. and Swart, P. K.: A kinetic difference between ${ }^{12} \mathrm{C}$ - and ${ }^{13} \mathrm{C}$-bound oxygen exchange rates results in decoupled $\delta^{18} \mathrm{O}$ and $\Delta_{47}$ values of equilibrating DIC solutions, Geochem. Geophy. Geosy., 19, 2371-2383, https://doi.org/10.1029/2018GC007500, 2018.

Tang, J., Dietzel, M., Fernandez, A., Tripati, A. K., and Rosenheim, B. E.: Evaluation of kinetic effects on clumped isotope fractionation $\left(\Delta_{47}\right)$ during inorganic calcite precipitation, Geochim. Cosmochim. Ac., 134, 120-136, https://doi.org/10.1016/j.gca.2014.03.005, 2014.

Thaler, C., Millo, C., Ader, M., Chaduteau, C., Guyot, F., and Ménez, B.: Disequilibrium $\delta^{18} \mathrm{O}$ values in microbial carbonates as a tracer of metabolic production of dissolved inorganic carbon, Geochim. Cosmochim. Ac., 199, 112-129, https://doi.org/10.1016/j.gca.2016.10.051, 2017.

Thiagarajan, N., Adkins, J., and Eiler, J.: Carbonate clumped isotope thermometry of deep-sea corals and implications for vital effects, Geochim. Cosmochim. Ac., 75, 4416-4425, https://doi.org/10.1016/j.gca.2011.05.004, 2011.
Tripati, A. K., Hill, P. S., Eagle, R. A., Mosenfelder, J. L., Tang, J., Schauble, E. A., Eiler, J. M., Zeebee, R. E., Uchikawa, J., Coplen, T. B., Ries, J. B., and Drew, H.: Beyond temperature: Clumped isotope signatures in dissolved inorganic carbon species and the influence of solution chemistry on carbonate mineral composition, Geochim. Cosmochim. Ac., 166, 344-371, https://doi.org/10.1016/j.gca.2015.06.021, 2015.

Urey, H. C., Lowenstam, H. A., Epstein, S., and McKinney, C. R.: Measurement of paleotemperatures and temperatures of the Upper Cretaceous of England, Denmark, and the south-eastern United States, Geol. Soc. Am. Bull., 62, 399-416, https://doi.org/10.1130/00167606(1951)62[399:MOPATO]2.0.CO;2, 1951.

Usdowski, E., Michaelis, J., Bottcher, M. E., and Hoefs, J.: Factors for the oxygen isotope equilibrium fractionation between aqueous and gaseous $\mathrm{CO}_{2}$, carbonic-acid, bicarbonate, carbonate, and water $\left(19^{\circ} \mathrm{C}\right)$, Z. Phys. Chem., 170, 237-249, 1991.

Watkins, J. M. and Hunt, J. D.: A process-based model for non-equilibrium clumped isotope effects in carbonates, Earth Planet. Sc. Lett., 432, 152-165, https://doi.org/10.1016/j.epsl.2015.09.042, 2015.

Watkins, J. M., Nielsen, L. C., Ryerson, F. J., and DePaolo, D. J.: The influence of kinetics on the oxygen isotope composition of calcium carbonate, Earth Planet. Sc. Lett., 375, 349-360, https://doi.org/10.1016/j.epsl.2013.05.054, 2013.

Zeebe, R. E. and Wolf-Gladrow, D.: $\mathrm{CO}_{2}$ in Seawater: Equilibrium, Kinetics, Isotopes, Elsevier Oceanography Book Series, Vol. 65, 346 pp., Elsevier Science, Amsterdam, 2001. 